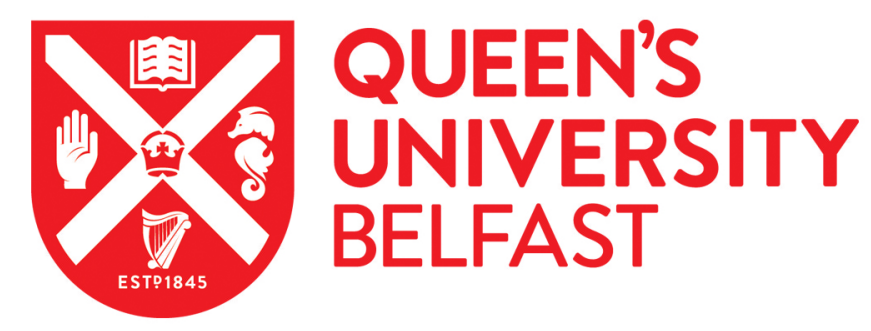

\title{
Assessing environmental controls on the distribution of long-chain alkenones in the Canadian Prairies
}

Plancq, J., Cavazzin, B., Juggins, S., Haig, H. A., Leavitt, P. R., \& Toney, J. L. (2018). Assessing environmental controls on the distribution of long-chain alkenones in the Canadian Prairies. Organic Geochemistry, 117, 43-55. https://doi.org/10.1016/j.orggeochem.2017.12.005

\section{Published in:}

Organic Geochemistry

Document Version:

Peer reviewed version

Queen's University Belfast - Research Portal:

Link to publication record in Queen's University Belfast Research Portal

Publisher rights

(c) 2017 Elsevier Ltd. All rights reserved.

This manuscript version is made available under the CC-BY-NC-ND 4.0 license http://creativecommons.org/licenses/by-nc-nd/4.0/,which permits distribution and reproduction for noncommercial purposes, provided the author and source are cited.

\section{General rights}

Copyright for the publications made accessible via the Queen's University Belfast Research Portal is retained by the author(s) and / or other copyright owners and it is a condition of accessing these publications that users recognise and abide by the legal requirements associated with these rights.

Take down policy

The Research Portal is Queen's institutional repository that provides access to Queen's research output. Every effort has been made to ensure that content in the Research Portal does not infringe any person's rights, or applicable UK laws. If you discover content in the Research Portal that you believe breaches copyright or violates any law, please contact openaccess@qub.ac.uk. 


\section{Accepted Manuscript}

Assessing environmental controls on the distribution of long-chain alkenones in the Canadian Prairies

Julien Plancq, Bianca Cavazzin, Steve Juggins, Heather A. Haig, Peter R. Leavitt, Jaime L. Toney

PII:

S0146-6380(17)30441-2

DOI: https://doi.org/10.1016/j.orggeochem.2017.12.005

Reference: OG 3659

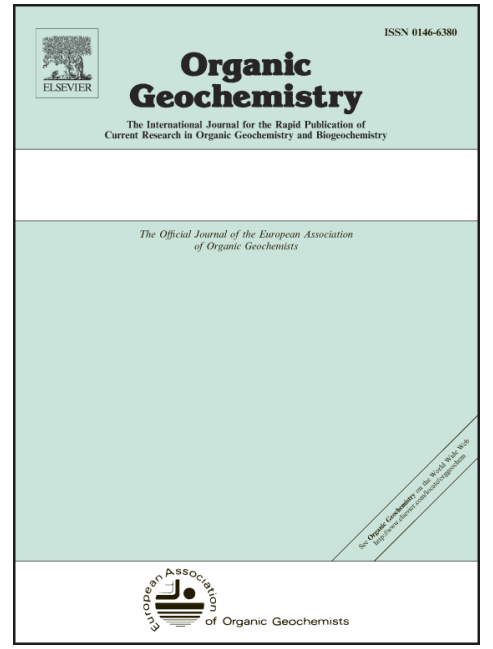

To appear in:

Organic Geochemistry

Received Date:

16 September 2017

Revised Date:

6 December 2017

Accepted Date:

14 December 2017

Please cite this article as: Plancq, J., Cavazzin, B., Juggins, S., Haig, H.A., Leavitt, P.R., Toney, J.L., Assessing environmental controls on the distribution of long-chain alkenones in the Canadian Prairies, Organic Geochemistry (2017), doi: https://doi.org/10.1016/j.orggeochem.2017.12.005

This is a PDF file of an unedited manuscript that has been accepted for publication. As a service to our customers we are providing this early version of the manuscript. The manuscript will undergo copyediting, typesetting, and review of the resulting proof before it is published in its final form. Please note that during the production process errors may be discovered which could affect the content, and all legal disclaimers that apply to the journal pertain. 
Assessing environmental controls on the distribution of long-chain alkenones in the Canadian Prairies

Julien Plancq ${ }^{a^{*}}$, Bianca Cavazzin ${ }^{a}$, Steve Juggins ${ }^{b}$, Heather A. Haig ${ }^{c}$, Peter R. Leavitt ${ }^{c}$, Jaime L. Toney ${ }^{\text {a }}$

${ }^{a}$ School of Geographical and Earth Sciences, University of Glasgow, Glasgow G12 8QQ, Scotland, UK

${ }^{\mathrm{b}}$ School of Geography, Politics and Sociology, Newcastle University, Newcastle-upon-Tyne, NE1 7RU, UK

${ }^{\mathrm{c}}$ Limnology Laboratory, Department of Biology, University of Regina, Regina, SK, S4S OA2, Canada

* Corresponding author. E-mail address: julien.plancq@glasgow.ac.uk; tel.: +44 (0) 1413305449. 


\section{ABSTRACT}

Long-chain alkenones (LCAs) have been used for decades to reconstruct quantitative sea-surface temperature records, but they also have a great potential for paleotemperature reconstructions in lacustrine settings. Here, we investigated how the presence and abundance of LCAs in surface sediments from 106 lakes varied with environmental conditions in lakes of the Northern Great Plains (Canadian Prairies) in southern Saskatchewan, Canada. Consistent with preliminary research, we found LCAs in 55\% of surveyed lakes, with mean concentrations of $143 \mu \mathrm{g} / \mathrm{g}$ dry sediment, but very high concentrations (up to $2.3 \mathrm{mg} / \mathrm{g}$ dry sediment) in $7 \%$ of lakes. Statistical analyses indicate that salinity and stratification play key roles in determining LCA presence and abundance supporting previous research in Spain and the northern Great Plains, USA. Overall, the alkenone unsaturation index $\left(U_{37}^{K}\right)$ was not correlated significantly with average summer water temperature, probably because the timing of maximum LCA production occurs during the spring season. We conclude that improved seasonal sampling is required within the study lakes to better identify the timing and habitat of haptophyte production, and allow development of environmental temperature reconstruction tools.

Keywords: alkenones, lakes, haptophyte, salinity, stratification, $\mathrm{U}_{37}^{\mathrm{K}}$.

\section{Introduction}

Long-chain alkenones (LCAs) are $\mathrm{C}_{35}-\mathrm{C}_{42}$ di-, tri- and tetra-unsaturated methyl and ethyl ketones whose biosynthesis in modern oceans is restricted to a few unicellular haptophyte algae of the order Isochrysidales, including the calcifying species (coccolithophores) Emiliania huxleyi and Gephyrocapsa oceanica (Volkman et al., 1980, 1995; Marlowe et al., 1984), and the coastal non-calcifying species Ruttnera lamellosa (formerly Chrysotila lamellosa) and Isochrysis galbana (Marlowe et al., 1984, 1990). The degree of unsaturation of $\mathrm{C}_{37}$ alkenones has been shown to vary as a function of the environmental temperature experienced during haptophyte growth (Brassell et al., 1986; Prahl and Wakeham, 1987), and the so-called alkenone unsaturation indices $\left(\mathrm{U}_{37}^{\mathrm{K}}, \mathrm{U}_{37}^{\mathrm{K}^{\prime}}\right)$ have been developed in both laboratory cultures and marine surface sediments as proxies for sea surface temperature (Prahl et al., 1988; Müller et al., 1998; Conte et al., 
2006). During the last three decades, the $U_{37}^{K^{\prime}}$ proxy has been successfully applied to reconstruct past marine temperature records at various sites and timescales (e.g., Rosell-Melé et al., 1995; Müller et al., 1998; Pahnke and Sachs, 2006).

More recently, LCAs have been reported worldwide in continental lakes (e.g., Cranwell, 1985; Zink et al., 2001; Chu et al., 2005; Longo et al., 2016). Unlike the open oceans, where the LCA production is believed to be limited to E. huxleyi and G. oceanica, genomic analyses from lacustrine sediments and particulate organic matter in lake water have shown the existence of multiple LCA-producing haptophyte species within and among the lakes (e.g., Coolen et al., 2004; D'Andrea et al., 2006; Theroux et al., 2010; Toney et al., 2012). Theroux et al. (2010) identified three distinct phylogenetic groups within the order Isochrysidales. Group I (aka “Greenland phylotype”: D’Andrea et al., 2006) seems to include haptophyte species restricted to freshwater and oligohaline lakes, whereas Group II includes R. lamellosa and I. galbana, as well as related species found in brackish waters and saline lakes. Group III includes the marine producers E. huxleyi and G. oceanica. In principle, the presence of multiple species complicates development of biogeochemical metrics of past lake temperatures as the relationship between temperature and the alkenone unsaturation index could differ between haptophyte species (Theroux et al., 2010; Toney et al., 2010; Randlett et al., 2014).

Moreover, the environmental parameters controlling alkenone distribution in inland waters remain unclear as LCAs have been found in freshwater (e.g., Zink et al., 2001; D'Andrea and Huang, 2005; Longo et al., 2013, 2016; D’Andrea et al., 2016) and saline lakes (e.g., Pearson et al., 2008; Liu et al., 2008, 2011; Toney et al., 2010; Zhao et al., 2014; Song et al., 2016), with ionic composition varying from sulfate-rich (e.g., Pearson et al., 2008; Toney et al., 2010) to carbonate-rich solutions (e.g., Chu et al., 2005; D’Andrea and Huang, 2005). Salinity has been suggested as an important factor on the occurrence and concentration of LCAs (D’Andrea and Huang, 2005; Lopez et al., 2005; Pearson et al., 2008; Toney et al., 2010; Liu et al., 2011; Chivall et al., 2014), with thresholds of salinity $(<3 \mathrm{~g} / \mathrm{L}$ and $>100 \mathrm{~g} / \mathrm{L})$ considered unsuitable for LCA producers to prosper (Liu et al., 2011; Song et al., 2016). In addition, seasonality of environmental variables (e.g., temperature, salinity, nutrients), especially in high latitude regions where lakes are ice covered during winter, may have a strong effect on phytoplankton succession (e.g., Lampert and Sommer, 
1997; Wetzel, 2001; Korkonen et al., 2017). In fact, lacustrine haptophytes experience sudden increase in abundance (bloom events), likely linked to seasonal changes in nutrient loading and irradiance levels (Toney et al., 2010; D’Andrea et al., 2011; Huguet et al., 2011; Theroux, 2012).

Despite these potential complications, LCAs have been demonstrated to vary with lake temperature in some sites, and a number of calibrations of the $\mathrm{U}_{37}^{\mathrm{K}}, \mathrm{U}_{37}^{\mathrm{K}^{\prime}}$, and $\mathrm{U}_{37}^{\mathrm{K}^{\prime \prime}}$ indices have been established in cultures (e.g., Sun et al., 2007; Toney et al., 2012; Theroux et al., 2013; Zheng et al., 2016) and in situ in freshwater (e.g., Zink et al., 2001; D’Andrea et al., 2011, 2016; Theroux et al., 2013; Longo et al., 2016) and saline lakes (e.g., Chu et al., 2005; Toney et al., 2010; Zheng et al., 2016). Together, these findings suggest that quantitative reconstruction of environmental temperature is possible.

The development of LCAs as metrics for past lacustrine temperatures may be important for the Great Plains of North America. This region is sensitive to temperature and moisture changes and often experiences prolonged periods of drought and floods that have major impacts on agriculture production and ecosystem function. Although lacustrine proxies for past droughts and pluvial intervals have been developed (e.g., diatom- and ostracod-inferred salinity; e.g., Cywinska and Delorme, 1995; Michels et al., 2007), there are few unambiguous proxies of past temperature in inland waters before the instrumental period. Quantitative paleotemperature reconstructions are thus crucial to help decipher the climate mechanisms responsible for drought occurrences. Studies from the northern Great Plains, USA (Theroux et al., 2010; Toney et al., 2010, 2012), suggest that LCA and haptophyte distributions may be suitable for quantitative temperature reconstruction, particularly at well-studied sites. Toney et al. (2011) reported the presence of LCAs in 13 lakes in the Canadian Prairies, southern Saskatchewan, where the development of an alkenone paleothermometer is particularly promising, because there appears to be only one haptophyte species present based on the LCA distribution. However, the low sample size $(n=19)$ was insufficient to conclusively determine which environmental parameters control the presence of LCA-producing haptophytes, or to derive a temperature calibration based on lacustrine surface sediments.

Here, we assess LCA presence and distributions in surface sediments collected from a broader survey of 87 additional lakes in the Canadian Prairies. Water chemistry data measured at the time of sampling for each lake allows us to better statistically constrain the environmental parameters favouring LCA presence and 
concentration in these 106 lakes. We also investigated the relationship between LCA and environmental temperature to further develop potential applications of an alkenone unsaturation index, such as $U_{37}^{\mathrm{K}}$.

\section{Methods}

\subsection{Sites and sampling}

Between July $29^{\text {th }}$ and August $30^{\text {th }}$ 2013, 106 lakes from the Canadian Prairies (southern Saskatchewan, Canada) (Fig. 1) were sampled during a field campaign for studies on modern drought risks and ecosystem sustainability. These lakes occur in the sub-humid (north east) to the semi-arid (south-west) areas of the Canadian Prairies, a region where evaporation exceeds precipitation by $20-60 \mathrm{~cm} / \mathrm{y}$ and lakes are sustained by the influx of snowmelt and groundwater (Pham et al., 2008, 2009). Climate data for the study region, obtained from the WorldClim database, indicate mean $( \pm S D)$ air temperatures and precipitation of; $2.5 \pm 1.0$ ${ }^{\circ} \mathrm{C}$ and $27.9 \pm 2.5 \mathrm{~mm}$ in spring, $16.9 \pm 0.7{ }^{\circ} \mathrm{C}$ and $56.9 \pm 6.0 \mathrm{~mm}$ in summer, $3.6 \pm 0.8^{\circ} \mathrm{C}$ and $23.6 \pm 4.1$ $\mathrm{mm}$ in autumn and $-14.2 \pm 2.0^{\circ} \mathrm{C}$ and $16.9 \pm 1.9 \mathrm{~mm}$ in winter. Survey lakes span a wide spatial extent of $4^{\circ}$ latitudinal gradient (Fig. 1) and a large range of salinity from fresh $(0.1 \mathrm{~g} / \mathrm{L})$ to hypersaline (102 $\left.\mathrm{g} / \mathrm{L}\right)$, with diverse ionic composition.

In situ lake parameters, including salinity, conductivity, $\mathrm{pH}$, depth and temperature, were measured at 0.5 $\mathrm{m}$ depth intervals (lakes < $10 \mathrm{~m}$ depth) or $1 \mathrm{~m}$ depth intervals (lakes $>10 \mathrm{~m}$ depth) for the entire water column using a YSI Pro Plus meter (YSI Inc., Yellow Springs, Ohio, USA) following Pham et al. (2008). Major ions including sodium $\left(\mathrm{Na}^{+}\right)$, chloride $\left(\mathrm{Cl}^{-}\right)$, calcium $\left(\mathrm{Ca}^{2+}\right)$, magnesium $\left(\mathrm{Mg}^{2+}\right)$, sulfate $\left(\mathrm{SO}_{4}{ }^{2-}\right)$, bicarbonate $\left(\mathrm{HCO}_{3}{ }^{-}\right)$, and carbonate $\left(\mathrm{CO}_{3}{ }^{2-}\right)$ were determined for each lake and analysed at the University of Alberta Water Chemistry Laboratory using standard procedures (Stainton et al., 1977). Water chemistry, especially surface salinity, of saline lakes may undergo significant changes over the seasonal cycles, and our in situ, one-time measurements of salinity may not capture the seasonal variation of ionic content in these lakes (Pham et al., 2009). However, while extremely dry years lead to spatially coherent increases in lake salinity from spring to later summer in the Canadian prairie lakes (Pham et al., 2009), there is little evidence 
of progressive increases in salinity in years with elevated precipitation despite a net precipitation deficit (Pham et al. 2009), such as those which preceded our 2013 survey. These patterns are described in detail as part of the Energy-mass flux framework, outlined in Leavitt et al. (2009). Thus, it is likely that salinity does not significantly change from spring to summer in most of our survey lakes.

Surface sediments were collected from each lake using an Ekman grab sampler. Subsamples of sediments (top $\mathrm{cm}$ of the collected sediments) were freeze-dried at $0.01 \mathrm{~Pa}$ for $36 \mathrm{~h}$ before use for analyses of organic constituents.

\subsection{LCA analyses}

Freeze-dried sediments were homogenized and extracted with dichloromethane (DCM):methanol $(\mathrm{MeOH})(9: 1, \mathrm{v}: \mathrm{v})$ using a Dionex model ASE350 accelerated solvent extractor. Following evaporation of the solvent, the total lipid extracts were separated into neutral and acid fractions by elution through a LC$\mathrm{NH}_{2}$ SPE column using DCM:isopropyl alcohol (1:1, v:v) followed by ether with $4 \%$ acetic acid (v:v) as eluents, respectively. The neutral fractions were further separated into four fractions of increasing polarity by chromatography over a silica gel column packed with 35-70 $\mu \mathrm{m}$ particles using hexane, DCM, ethyl acetate:hexane (1:3, v:v) and $\mathrm{MeOH}$ as eluents.

LCAs are contained in the second fraction (DCM) and were detected and quantified using gas chromatography with a flame-ionization detector (GC-FID). To remove compounds that can co-elute with LCAs such as alkenoates, LCA fractions were saponified by heating at $60{ }^{\circ} \mathrm{C}$ overnight in $1 \mathrm{~N} \mathrm{KOH}$ in $\mathrm{MeOH}: \mathrm{H}_{2} \mathrm{O}(95: 5, \mathrm{v}: \mathrm{v})$. After heating, the reaction mixture was cooled to room temperature, quenched with $\mathrm{NaCl}$ ( $5 \%$ by volume), extracted using hexane, and rerun on the GC-FID.

GC-FID analyses were performed on an Agilent 7890B Series GC system configured with an Agilent VF-200 ms capillary column (60 m length, $0.25 \mathrm{~mm}$ i.d., $0.10 \mu \mathrm{m}$ film thickness) (Longo et al., 2013). Hydrogen was used as the carrier gas at a $36 \mathrm{~cm} / \mathrm{s}$ column flow rate. The GC method used splitless injection $\left(320{ }^{\circ} \mathrm{C}\right.$ ), and the oven temperature was programmed from $50{ }^{\circ} \mathrm{C}$ (hold for $1 \mathrm{~min}$ ) to $255^{\circ} \mathrm{C}$ at $20{ }^{\circ} \mathrm{C} / \mathrm{min}$, then to $300{ }^{\circ} \mathrm{C}$ at $3{ }^{\circ} \mathrm{C} / \mathrm{min}$, followed by $10{ }^{\circ} \mathrm{C} / \mathrm{min}$ increase to $320^{\circ} \mathrm{C}$ and hold for $10 \mathrm{~min}$. Samples were 
also run with the same temperature program on an Agilent 7890B Series GC coupled with a 5977A GC-EI mass spectrometer (GC-MS) to confirm the identity of the LCAs using the known ion chromatograms and by comparison of mass spectral data and GC retention times with published data (de Leeuw et al., 1980; Marlowe et al., 1984). LCAs were quantified using hexatriacontane ( $n-\mathrm{C}_{36}$ alkane) as an internal standard added to the sample before injection. The reproducibility achieved for duplicate LCA quantifications was estimated to be better than $\pm 10 \%$ (coefficient of variation). The alkenone unsaturation index $U_{37}^{\mathrm{K}}$ and other indices (for example $U_{37}^{K^{\prime}}, U_{37}^{K^{\prime \prime}}, U_{38}^{K}$ ) were calculated for all lakes following Brassell et al. (1986), Pearson et al. (2008), and Zheng et al. (2016). LCA distribution parameters such as $\mathrm{C}_{37} / \mathrm{C}_{38}$ (Volkman et al., 1995), \% $\mathrm{C}_{37: 4}$ (Rosell-Melé, 1998), and RIK 37 (Longo et al., 2016) were also computed.

\subsection{Statistical analyses}

Approximately $45 \%$ of the lakes sampled had LCAs below detection limit and where present, LCAs showed a strong right-skewed distribution. Consequently, the relationships between LCAs and environmental parameters were modelled using a two-stage hurdle process (Zuur et al., 2012) that models the presence-absence of LCAs and LCA concentration as two distinct processes. For the first part, or "hurdle", we used a binomial generalised linear model based on the full dataset to model the presence and absence of LCAs above/below the detection limit. For observations with LCAs above the detection limit (i.e., those that crossed the hurdle), we modelled LCA concentration as a function of selected environmental variables using a log-normal model. The hurdle model considers presence/absence and concentration of LCAs separately, which is appropriate as environmental factors controlling LCA presence may be different from those controlling LCA concentration once observed (Taranu et al., 2017). Limnological datasets such as ours contain large numbers of potential predictors which are often highly intercorrelated. Variable selection is often used to find the "minimum adequate model" that contains a small subset of variables that explains, in a statistical sense, the data as well as the full set. However, variable selection with highly correlation predictors is problematic (Whittingham et al., 2006), and it is increasingly recognised that there is no "best" model, but often a series of models that explain the data equally well. 
Predictive models were developed to account for the observation that many limnological variables are potentially correlated. For both parts of the hurdle model, we tested the significance of each variable (water chemistry, limnological, climatic, landscape) separately using a chi-squared or F test for the presenceabsence and concentration models, respectively. We then fitted a large set of models using all combinations of the subset of significant variables (Calcagno and Mazancourt, 2010). Using this set of models, we then used Akaike's Information Criterion (AIC) to identify: (a) the best model, and (b) all other models within 2 AIC units of the best model, as these are effectively indistinguishable from the best model and are equally plausible. We then fitted a final model using the list of predictor variables that appear in any of the selected models.

Variance partitioning of either the variance explained for the log-normal model or pseudo- $\mathrm{r}^{2}$ (binomial model; Nagelkerke, 1991) was used to quantify the importance or explanatory power of each predictor in the final model and to decompose the explained variance into independent and shared components (Borcard et al., 1992). To provide an additional visualisation of the relationship between LCAs and environmental factors, we used classification and regression trees (CARTs) to model LCA presence and absence, and concentration, respectively. CARTs are binary recursive tree-based models that identify a set of decision rules that best predicts either a binary outcome (classification trees) or quantitative variable (regression tree). At each stage of fitting a CART tree, the algorithm identifies a variable and threshold value that best predicts the response variable. Since our interest here is in explanation rather than prediction, we used AIC to identify the best tree rather than cross-validation (Hothorn and Zeileis, 2015). CARTs have the disadvantage that they can only display a single model, when there may be several best models, but have the advantage that they can reveal interactions between variables not easily visualised using other methods (Hastie et al., 2009).

The relationships between various alkenone-based indices $\left(\% \mathrm{C}_{37: 4}, \mathrm{C}_{37} / \mathrm{C}_{38} ; \mathrm{U}_{37}^{\mathrm{K}}, \mathrm{U}_{37}^{\mathrm{K}^{\prime}}, \mathrm{U}_{37}^{\mathrm{K}^{\prime \prime}}\right)$, alkenone isomer composition, and environmental factors were further explored using linear regressions and constrained ordinations. For the latter, we assessed the significance and importance of each predictor with a Monte Carlo permutation test and variance partitioning respectively (Borcard et al., 2011). 
The distribution of LCA concentration and many of the explanatory variables showed a right-skewed distribution: these were either $\log _{10}$ (all water chemistry, lake area, LCA concentration) or square-root(sample depth) transformed prior to analysis to normalize their distributions. We also included average air temperature, obtained from the WorldClim database with a spatial resolution of approximately $1 \mathrm{~km}^{2}$.

All statistical analyses were performed using $\mathrm{R}$ software for statistical computing and graphics ( $\mathrm{R}$ Development Core Team, 2017) with the following packages: glmulti (Calcagno and Mazancourt, 2010), vegan (Oksanen et al., 2017), and partykit (Hothorn and Zeileis, 2015).

\section{Results}

\subsection{Environmental data}

Survey lakes exhibited large gradients for most environmental parameters (Table 1 and Supplementary Table S1) including depth $(0.1-28.5 \mathrm{~m})$, salinity $(0.1-102.2 \mathrm{~g} / \mathrm{L})$ and mean water temperature $\left(8.6-23.7^{\circ} \mathrm{C}\right)$. In general, individual lakes had higher concentrations of sulfate $\left(\mathrm{SO}_{4}{ }^{2-}\right)(31.5-120,223 \mathrm{mg} / \mathrm{L})$ than bicarbonate $\left(\mathrm{HCO}_{3}{ }^{-}\right)(156-5625 \mathrm{mg} / \mathrm{L})$, carbonate $\left(\mathrm{CO}_{3}{ }^{2-}\right)(<0.01-5528 \mathrm{mg} / \mathrm{L})$ or chloride $\left(\mathrm{Cl}^{-}\right)(3.1-45,022$ $\mathrm{mg} / \mathrm{L})$. In addition, lakes exhibited different degrees of thermal and chemical stratification, ranging from polymixis to permanent stratification (meromixis). Chemistry and hydrology of about two-thirds of these lakes has been discussed in Pham et al. (2009). Elevated sulfate concentration in the Saskatchewan region is mostly derived from oxidation of the underlying bedrock (Last and Ginn, 2005; Hayashi and van der Kamp, 2009).

\subsection{LCA occurrence and abundances}

Of the 106 lake surface sediments examined in this study, 58 (55\%) contained detectable concentrations of LCAs (Fig. 1; Table 1). Total concentrations of LCAs range from 2.5 to 27,625 $\mu \mathrm{g} / \mathrm{g}$ TOC $(0.02-2,312$ $\mu \mathrm{g} / \mathrm{g}$ dry sediment), with very high concentrations (> $1000 \mu \mathrm{g} / \mathrm{g}$ TOC or $100 \mu \mathrm{g} / \mathrm{g}$ dry sediment) recorded in 
nine of the LCA-containing lakes (15\% of basins) (Table 1). The highest concentrations of LCAs generally occurred in the northern section of the sampling area (> 51 ${ }^{\circ} \mathrm{N}$; Fig. 1).

The majority of LCA-containing surface sediments (53\%) featured high $\% \mathrm{C}_{37: 4}$, with values $>60 \%$. Five lakes featured a profile mainly composed of the $\mathrm{C}_{37: 3}$ alkenone $\left(\% \mathrm{C}_{37: 4}<40 \%\right)$ (Fig. 2). In addition, one lake displayed a predominance of $\mathrm{C}_{38}$ alkenones over $\mathrm{C}_{37}$ alkenones, with particularly elevated concentrations of the $\mathrm{C}_{38: 3}$ alkenone (Fig. 2). Among the lakes, four of them showed the presence of the $\mathrm{C}_{37: 3 \mathrm{~b}}$ alkenone isomer, including one freshwater $(<0.5 \mathrm{~g} / \mathrm{L})$ and three oligohaline $(0.5-5 \mathrm{~g} / \mathrm{L})$ lakes (Table 1 and Fig. 2). RIK $_{37}$ (ratio between $\mathrm{C}_{37: 3 \mathrm{a}}$ and $\mathrm{C}_{37: 3 \mathrm{~b}}$ isomers; Longo et al., 2016) values were in the range 0.47-0.57 (Table 1). $\mathrm{C}_{37} / \mathrm{C}_{38}$ ratios varied between 0.4 and 7.7 , with a mean value of $2.7 \pm 1.7$ (Table 1 ). No significant correlation was found between the $\mathrm{U}_{37}^{\mathrm{K}}$ unsaturation index and depth-integrated water column temperature or surface water temperature at the time of sampling (August 2013), or with air (spring or summer) temperature. No significant correlation was found using other indices (such as the $U_{37}^{K \prime}, U_{37}^{K \prime}$, or the $U_{38}^{K}$ ), or through regression analysis of individual LCAs with air (spring or summer) and water temperature.

\subsection{Factors influencing LCA presence and concentration}

Fig. 3 shows the significant predictor variables explaining the presence/absence of LCAs, the explanatory power (variance) of each variable, and the explained variance decomposed into independent and shared components. Salinity, water $\mathrm{pH}$, depth, water temperature and stratified (stratification of the lake) were the most significant predictor variables explaining the occurrence of LCAs in the Canadian prairie lakes (Supplementary Table S2). Salinity was the most important variable (24\% of variance explained), and most of the variation explained by salinity (20\%) was independent of other variables. Water pH explained a small part (3.5\%), but its explanatory power was mostly independent of other parameters. Stratified, depth and water temperature explained moderate amounts of variability $(5 \%, 11 \%$ and $14 \%$, respectively), but their explanatory powers were largely confounded with each other.

To provide an additional visualisation of the relationship between LCAs and environmental factors, we used a classification tree (Fig. 4). A split in salinity at $2.4 \mathrm{~g} / \mathrm{L}$ was observed, representing a threshold for the 
presence of LCAs. At low salinity $(<2.4 \mathrm{~g} / \mathrm{L})$, stratification was important for the presence of LCA, but LCAs were rare in lakes with high $\mathrm{pH}(>8.5)$. At higher salinity $(>2.4 \mathrm{~g} / \mathrm{L})$, LCAs were rare in shallow lakes $(<0.6 \mathrm{~m})$. LCAs occurred mainly in deeper lakes $(>0.6 \mathrm{~m})$, but they were slightly less common in very saline lakes (> $44.4 \mathrm{~g} / \mathrm{L})$.

Salinity, depth, water temperature and presence of stratification were the most significant predictor variables of modelled LCA concentrations (Fig. 5 and Supplementary Table S2). Salinity was the most important variable (31\% of variance explained), and most of the variation explained by salinity was independent of other variables. Depth explained a much smaller proportion of variance $(7 \%)$ and its explanatory power was entirely confounded with other variables. Stratification and water temperature explained moderate amounts (16\% and $24 \%$, respectively), although their explanatory powers were largely confounded with each other. The regression tree (Fig. 6) showed a salinity threshold of $4.9 \mathrm{~g} / \mathrm{L}$. A further distinction was noted at low salinities $(<4.9 \mathrm{~g} / \mathrm{L})$, with slightly higher LCA concentrations between 0.8 and $4.9 \mathrm{~g} / \mathrm{L}$ than in less saline waters. At higher salinities $(>4.9 \mathrm{~g} / \mathrm{L})$, LCAs showed higher concentrations in stratified lakes than in unstratified basins.

Relative (\%) importance of carbonate and sulfate and metrics of total salinity were identified as the main predictors of alkenone isomer compositions, but the explained variances were generally low $(8.2 \%, 5 \%$ and $2.5 \%$, respectively). Most variation explained by carbonate (4.6\%) was independent of other variables, whereas the explanatory power of sulfate $(4.8 \%)$ and salinity (1.4\%) was largely confounded with other variables.

Statistical analyses between various LCA-based indices and environmental factors showed a significant but weak relationship between $\%$ carbonate (among anions) and $\% \mathrm{C}_{37: 4,} \mathrm{U}_{37}^{\mathrm{K}}, \mathrm{U}_{37}^{\mathrm{K} \text { ", or }} \mathrm{C}_{37} / \mathrm{C}_{38}$ (Supplementary Table S2). No significant relationship was found between salinity and $\% \mathrm{C}_{37: 4}$, or between salinity and $\mathrm{U}_{37}^{\mathrm{K}}$, $\mathrm{U}_{37}^{\mathrm{K}^{\prime \prime}}$, or $\mathrm{C}_{37} / \mathrm{C}_{38}$ (Supplementary Table $\mathrm{S} 2$ ). For the $\mathrm{U}_{37}^{\mathrm{K}^{\prime}}$ index, no significant correlation was observed with any environmental variables.

\section{Discussion}


The majority of LCA-containing lakes showed high proportion of $\mathrm{C}_{37: 4}$ alkenone (Fig. 2), which is a common feature of lacustrine systems (e.g., Sun et al., 2004; D’Andrea et al., 2011; Longo et al., 2016). A large variation in $\mathrm{C}_{37} / \mathrm{C}_{38}$ ratio values (0.5-7.7; mean 3.3) was observed in these lakes, but values were in the same range as those recorded for Isochrysis galbana and Ruttnera lamellosa (Marlowe et al., 1984; Rontani et al., 2004) and lakes within the US Great Plain sites (Toney et al., 2010). In contrast, five Canadian lakes were characterized by elevated $\mathrm{C}_{37: 3}$ alkenone content (Fig. 2), a profile typical of offshore marine environments (e.g., Prahl et al., 1988; Sikes and Volkman, 1993) and rarely reported in lacustrine sediments (e.g., Li et al., 1996; Theissen et al., 2005; Toney et al., 2010; Hou et al., 2016). These lakes present lower $\mathrm{C}_{37} / \mathrm{C}_{38}$ ratio variations and values $(1.4-2.4$; mean value $=1.8)$ similar to those recorded for $E$. huxleyi (Marlowe et al., 1984), from Chinese lakes (Sun et al., 2004; Chu et al., 2005), and in US sites with $\mathrm{C}_{37: 3^{-}}$ dominant profiles (Toney et al., 2010). Finally, a single lake displayed a predominance of $\mathrm{C}_{38}$ over $\mathrm{C}_{37}$ LCAs, with especially elevated levels of tri-unsaturated components. A few lacustrine studies have reported such a profile in alkaline, evaporitic or saline settings (Thiel et al., 1997; Sun et al., 2004; Chu et al., 2005; Pearson et al., 2008). The $\mathrm{C}_{37} / \mathrm{C}_{38}$ ratio was low (0.4) for this particular lake and very similar to that of the Spanish lakes (mean value $=0.1)$ studied by Pearson et al. $(2008)$. Pearson et al. (2008) suggested that salinity may play a role in LCA composition, with a salinity threshold of $40 \mathrm{~g} / \mathrm{L}$ for $\mathrm{C}_{37} \mathrm{LCAs}$ and $\mathrm{C}_{38^{-}}$ dominated LCA profiles being characteristic of hypersaline lakes. In contrast, the sole basin with $\mathrm{C}_{38}$ LCAs reported here was not hypersaline $(10 \mathrm{~g} / \mathrm{L})$ and we report that $\mathrm{C}_{37}$ LCAs were also present in one lake with salinity $>40 \mathrm{~g} / \mathrm{L}$ (Table 1), suggesting that salinity, per se, is not the sole factor influencing the dominance of $\mathrm{C}_{38}$ alkenones.

Differences in LCA profiles among basins may reflect variation in the community composition of LCAproducing haptophyte species in the studied Canadian lakes. Studies in the US Great Plains (Toney et al., 2010, 2012; Theroux et al., 2010) showed the presence of two haptophyte species from Group II among and within saline lakes, with OTU7 haptophyte or Hap B producing mainly $\mathrm{C}_{37: 3}$ alkenones, while OTU8 haptophyte or Hap A produces predominantly $\mathrm{C}_{37: 4}$ alkenones. Part of the reason for this difference in 
distribution can be attributed to the offset in the timing of their bloom, where Hap A blooms in the early spring during low temperatures $\left(2-12^{\circ} \mathrm{C}\right)$ and Hap B blooms nearly a month later with a temperature range of $\left(12-18{ }^{\circ} \mathrm{C}\right)$ (Theroux, 2012). In addition, Toney et al. (2012) showed that Hap A species dominates LCA production in sulfate-rich lakes (sulfate:carbonate ratio SCR > 1), while production is dominated by Hap B in carbonate-dominated lakes with SCR $<1$. Here, the majority of the study lakes were sulfate-rich with SCR values much greater than one, except for Reflex Lake (Table 1 and Supplementary Table S1). All together, these observations would suggest that Hap A and Hap B are mainly responsible for the sedimentary LCA profile in the Canadian lakes, with few exceptions.

The Group I phylotype also thrived in some of the Canadian freshwater $(<0.5 \mathrm{~g} / \mathrm{L})$ and oligohaline $(0.5-$ $5 \mathrm{~g} / \mathrm{L}$ ) lakes, as suggested by Longo et al. (2016) based on the presence of the alkenone isomer $\mathrm{C}_{37: 3 \mathrm{~b}}$. The RIK $_{37}$ index (ratio between $\mathrm{C}_{37: 3 \mathrm{a}}$ and $\mathrm{C}_{37: 3 \mathrm{~b}}$ isomers) has also been proposed as a taxonomic indicator for multi-species effects, with RIK $_{37}$ values of $0.51-0.60$ indicating lakes hosting only Group I haptophytes and $\mathrm{RIK}_{37}$ values of 0.60-1.0 indicating lakes containing both Group I and Group II haptophytes (Longo et al., 2016). In this study, we found the $C_{37: 3 b}$ isomer in four lakes (Fig. 2), including one freshwater and three oligohaline lakes, and RIK $_{37}$ values of 0.47-0.57 (Table 1), indicating the exclusive presence of Group I haptophytes in these lakes. In all other sites, $\mathrm{RIK}_{37}$ values of $1\left(\mathrm{C}_{37: 3 \mathrm{~b}}\right.$ isomer absent $)$ suggest the exclusive presence of Group II haptophytes. Given these patterns, we will conduct genomic analyses in the future to confirm the presence of Hap A, Hap B, and Group I haptophytes in these Canadian lakes.

\subsection{Relationship between LCAs and environmental parameters}

Overall, our statistical analyses of the relationship between LCA distribution and major environmental gradients showed that LCA occurrence and abundance was influenced by a combination of salinity, water temperature, basin morphometry (depth), and water column stratification (Figs. 3-6). These results are consistent with previous studies that have shown that LCA abundance is generally higher in lakes with elevated sulfate content and salinity (e.g., Pearson et al., 2008; Toney et al., 2010; Liu et al., 2011; Zhao et al., 2014). Sulfate content does not appear as a main variable for LCA distribution in our statistical analyses, 
likely because most of our study lakes are actually sulfate-rich. In contrast, salinity appears as a main factor on LCA presence and abundance. Salinity thresholds highlighted in our statistical analyses $(2.4-44.4 \mathrm{~g} / \mathrm{L})$ support the observation that higher LCA concentrations occur in brackish/saline lakes rather than in fresh and hypersaline lakes (e.g., Liu et al, 2011; Song et al., 2016).

While salinity is the main variable regulating LCAs in this study, it was more difficult to separate the unique effects of water temperature (more LCAs with lower temperature), depth and stratification, likely because the thermal regime varied with the degree of lake stratification. In fact, highest LCA concentrations are generally recorded in lakes exhibiting permanent stratification and deep-water anoxia (Table 1).

Stratification and deep-water anoxia have been suggested to play a role in LCA abundance in relation to the life cycle of lacustrine haptophytes (Toney et al., 2010). In the US Great Plains, the movement of LCAs within the water column is affected mainly by the degree of mixing and stratification experienced during the haptophyte bloom (Toney et al., 2010). Indeed, it appears that lacustrine haptophytes include a benthic vegetative stage within their life cycle (Toney et al., 2010), as recently shown for the marine haptophyte Isochrysis galbana (Ellegaard et al., 2016). In addition, some lacustrine phytoplankton cells survive during the winter season as resting cells in the bottom sediment (Salmi and Salonen, 2016). Thus, we conclude that bottom waters could represent a physical "refuge" for haptophyte cells during times of the year when conditions are unsuitable for population growth, such as winter.

In the Canadian Prairies, elevated sulfate content, derived from oxidation of pyrite in the underlying bedrock, is common in lakes that have significant groundwater contribution (Last and Ginn, 2005; Hayashi and van der Kamp, 2009). This environmental sulfur (as sulfate) is an essential element for all photosynthetic algae (e.g., Takahashi et al., 2011; Giordano and Prioretti, 2015); however, the influx of sulfate-rich groundwater could also favor chemical stratification (meromixis) and deep-water anoxia (Pham et al., 2008, 2009). Thus, at present, it is unclear how biotic demand and abiotic factors may interact to favour haptophytes and LCA production or preservation. In particular, further studies will be needed to further assess the influence of sulfate on LCAs and determine whether high LCA concentration in these Canadian lakes is the result of increased production or merely improved post-depositional preservation in the anoxic, aphotic bottom waters (Leavitt, 1993). 
While the vast majority of our Canadian study lakes are saline, our survey also included 25 freshwater lakes (Table 1). Only 6 of these freshwater lakes contained detectable LCAs and our statistical analyses showed that LCAs occurred mainly in stratified alkaline freshwater lakes with pH up to 8.5 (Fig. 4). These observations are consistent with those in Alaskan freshwater lakes, where high LCA concentration was found in deep lakes with high $\mathrm{pH}$, alkalinity and conductivity (Longo et al., 2016). Interestingly, these patterns suggest that the main environmental parameters influencing LCA occurrence and abundance may differ between freshwater and saline lakes, although it is still unclear how salinity, morphology, and stratification may interact with the basic biology of LCA-producing haptophytes.

\subsection{Relationship between LCA-based indices and environmental parameters}

The $\% \mathrm{C}_{37: 4}$ has been suggested as a salinity proxy as the relative proportion of the $\mathrm{C}_{37: 4}$ alkenone has been reported to vary inversely with salinity in marine (e.g., Rosell-Melé, 1998; Schulz et al., 2000; Kaiser et al., 2017) and lacustrine environments (e.g., Liu et al., 2008, 2011; Song et al., 2016). As with some previous works (e.g., Sikes and Sicre, 2002; Toney et al., 2010), we found no significant relationship of \% $\mathrm{C}_{37: 4}$ with salinity (Supplementary Table S2), possibly because the production of $\mathrm{C}_{37: 4}$ alkenone varies among haptophyte species and strains (Theroux et al., 2010). The $U_{37}^{K}$ and $U_{37}^{K \prime \prime}$ indices, which include the $C_{37: 4}$ alkenone in their definition, are also not influenced by salinity variation (Supplementary Table S2), conversely to what has been observed in Chinese lakes (Liu et al., 2011; Song et al., 2016). On the other hand, a significant but weak correlation was observed between the relative abundance of $\mathrm{C}_{37: 4}$ alkenone and relative importance of carbonate among anions (Supplementary Table S2). Similarly, a significant but weak correlation was found between $\mathrm{U}_{37}^{\mathrm{K}}, \mathrm{U}_{37}^{\mathrm{K} \text { " }}$ and the \% carbonate (Supplementary Table $\mathrm{S} 2$ ). The effect of carbonate on the proportion of $\mathrm{C}_{37: 4}$ alkenone, if any, remains unknown.

\subsection{Relationship between LCA unsaturation indices and temperature}


Although temperature was a substantial (24\%) predictor of variation in LCA concentrations in the statistical analyses of lake survey data, there was no significant relationship between mean water column temperature at the time of sampling (August 2013) and common indices of environmental temperature $\left(U_{37}^{K}, U_{37}^{K^{\prime}}, U_{37}^{K^{\prime \prime}}\right.$, or $\left.U_{38}^{K}\right)$. This lack of correlation may reflect the fact that temperature data was estimated on only a single date in August, while $1 \mathrm{~cm}$ deep sediment samples integrate historical haptophyte populations at the scale from seasons to years. Furthermore, late summer does not necessarily correspond to the time of maximum haptophyte production. For example, Toney et al. (2011) obtained a weak but positive and statistically significant correlation $\left(r^{2}=0.30, p=0.067\right)$, with average surface temperature recorded in spring in some of these lakes, suggesting a predominantly cool-season life cycle of haptophytes. The slope of the relationship was also similar to that derived from site-specific calibration of the $U_{37}^{K}$ index in Lake George, North Dakota, suggesting that the change in LCA unsaturation as a function of temperature is similar between Great Plains lakes in the US and Canada. In fact, when we apply the temperature calibration of Lake George (Toney et al., 2010) at one site for which we have measured water temperature data for 20 years (Diefenbaker Lake), the LCA-inferred temperature is $11.9^{\circ} \mathrm{C}$, which is very close to the average water temperature in June $\left(11.2^{\circ} \mathrm{C}\right)$ and the average air temperature in the preceding month (May) recorded at a nearby weather station $\left(10.9{ }^{\circ} \mathrm{C}\right.$; Elbow Cs weather station).

As the LCA profile at Lake Diefenbaker suggests the presence of Group I haptophyte, we also applied the three in situ temperature calibrations currently developed for lakes where the presence of Group I phylotype has been confirmed (D'Andrea et al., 2011, 2016; Longo et al., 2016). Here, the LCA-inferred temperature varied between $6.2^{\circ} \mathrm{C}$ and $12.1{ }^{\circ} \mathrm{C}$, values which were close to the average water temperature in May (6.8 $\left.{ }^{\circ} \mathrm{C}\right)$ or June $\left(11.2^{\circ} \mathrm{C}\right)$. Together, these data support the idea that haptophyte blooms occur in spring after iceout (Toney et al., 2010). Unfortunately, year-round estimates of water temperature were not available for the study lakes and we did not find any correlation with air temperature data for the spring season from weather stations close to the studied lakes.

Weak correlation between the LCA unsaturation indices and environmental temperature may also reflect the presence of multiple haptophyte species with different thermal optima (e.g., Hap A and Hap B), in a single lake. For example, Hap A produces mainly $\mathrm{C}_{37: 4}$ alkenones and blooms during spring, whereas Hap B 
produces mainly $\mathrm{C}_{37: 3}$ alkenones and blooms during summer (Theroux, 2012). However, we did not find any significant correlations with spring air temperature for lakes with high $\% \mathrm{C}_{37: 4}$ and with summer air temperature for lakes with low $\% \mathrm{C}_{37: 4}$. This is likely because the temperature calibration throughout the bloom events, which combines Hap A and Hap B temperature calibrations, is actually very similar to the in situ lake calibration of Toney et al. (2010) (Theroux, 2012). Instead, we suggest that establishment of a valid calibration of environmental conditions and the $U_{37}^{K}$ index may require more intensive field sampling during the haptophyte bloom in select candidate lakes to quantify the seasonality of LCA production and the appropriate environmental temperature for comparison (Toney et al., 2010).

\section{Conclusions}

Long-chain alkenones are common in the Canadian lakes of the northern Great Plains, and their presence and abundance is influenced by a combination of salinity, water temperature, depth, and degree of watercolumn stratification. Based on this study, sulfate may play a role in LCA distribution, even though it is unclear if its effect is related to biological requirements or to change in the aquatic environment (groundwater, stratification, etc.). While these environmental parameters clearly play a role in regulating the life cycle of the LCA-producing haptophytes, further studies will be essential to define how haptophyte ecology varies with seasonal and inter-annual changes in lake conditions. LCA profiles suggested that most lakes contained haptophyte species from the Group II phylotype, likely closely related to OTU8 haptophyte (Hap A) and OTU7 haptophyte (Hap B) found in the US Great Plains. However, while the presence of other species from the Group I phylotype was also confirmed, we note that they were not particularly common. Unexpectedly, we were not able to calibrate the LCA unsaturation ratios $\left(U_{37}^{K}, U_{37}^{K^{\prime}}, U_{37}^{K^{\prime \prime}}\right.$ or $\left.U_{38}^{K}\right)$ with environmental conditions at this time. Instead, further studies with a more intensive sampling at different depths and seasons will be needed to calibrate the $U_{37}^{K}$ index in situ with the appropriate environmental temperature. Genomic analyses will also be important to precisely determine the haptophyte species present in these Canadian lakes. 


\section{Acknowledgements}

We thank Philip Meyers, Yongsong Huang and an anonymous reviewer for their constructive comments that helped to significantly improve the quality of the manuscript. This study was funded by the ERC Starting Grant 2014 (637776 ALKENoNE) to JLT, and by NSERC Canada, the Canada Research Chair, Canada Foundation for Innovation, Province of Saskatchewan, and University of Regina to PRL.

\section{Associate Editor-Philip Meyers}

\section{References}

Borcard, D., Legendre, P., Drapeau, P., 1992. Partialling out the spatial component of ecological variation. Ecology 73, 1045-1055.

Borcard, D., Gillet, F., Legendre, P., 2011. Numerical Ecology with R. Springer, Dordrecht.

Brassell, S.C., Brereton, R.G., Eglinton, G., Grimalt, J., Liebezeit, G., Marlowe, I.T., Pflaumann, U., Sarnthein, M., 1986. Palaeoclimatic signals recognized by chemometric treatment of molecular stratigraphic data. Organic Geochemistry 10, 649-660.

Calcagno, V. Mazancourt, C.D., 2010. glmulti: An R package for easy automated model selection with (generalized) linear models. Journal of Statistical Software 34. DOI: 10.18637//jss.v034.i12.

Chivall, D., M’Boule, D., Sinke-Schoen, D., Sinninghe Damsté, J.S., Schouten, S., van der Meer, M.T.J., 2014. Impact of salinity and growth phase on alkenone distributions in coastal haptophytes. Organic Geochemistry 67, 31-34.

Chu, G., Sun, Q., Li, S., Zheng, M., Jia, X., Lu, C., Liu, J., Liu, T., 2005. Long-chain alkenone distributions and temperature dependence in lacustrine surface sediments from China. Geochimica et Cosmochimica Acta 69, 4985-5003.

Conte, M.H., Sicre, M.-A., Rühlemann, C., Weber, J.C., Schulte, S., Schulz-Bull, D., Blanz, T., 2006. Global temperature calibration of the alkenone unsaturation index $\left(\mathrm{U}_{37}^{\mathrm{K}^{\prime}}\right)$ in surface waters and 
comparison with surface sediments. Geochemistry, Geophysics, Geosystems 7.

http://dx.doi.org/10.1029/2005GC001054.

Coolen, M.J.L., Muyzer, G., Rijpstra, W.I.C., Schouten, S., Volkman, J.K., Sinninghe Damsté, J.S., 2004. Combined DNA and lipid analyses of sediments reveal changes in Holocene haptophyte and diatom populations in an Antarctic lake. Earth and Planetary Science Letters 223, 225-239.

Cranwell, P.A., 1985. Long-chain unsaturated ketones in recent lacustrine sediments. Geochimica et Cosmochimica Acta 49, 1545-1551.

Cywinska, A., Delorme, L.D., 1995. Paleoenvironmental interpretations using fossil freshwater ostracodes from Clearwater Lake core site, Saskatchewan, and Max Lake, Manitoba. National Water Research Institute, Burlington, Ontario, NWRI Contribution 95-1-7, 43 pp.

D’Andrea, W.J., Huang, Y., 2005. Long-chain alkenones in Greenland lake sediments: Low $\delta^{13} \mathrm{C}$ values and exceptional abundance. Organic Geochemistry 36, 1234-1241.

D'Andrea, W.J., Lage, M., Martiny, J.B.H., Laatsch, A.D., Amaral-Zettler, L.A., Sogin, M.L., Huang, Y., 2006. Alkenone producers inferred from well-preserved 18S rDNA in Greenland lake sediments. Journal of Geophysical Research 111, G03013.

D’Andrea, W.J., Huang, Y., Fritz, S.C., Anderson, N.J., 2011. Abrupt Holocene climate change as an important factor for human migration in West Greenland. Proceedings of the National Academic of Sciences of the United States of America 108, 9765-9769.

D’Andrea, W.J., Theroux, S., Bradley, R.S., Huang, X., 2016. Does phylogeny control U ${ }_{37}^{\mathrm{K}}$-temperature sensitivity? Implications for lacustrine alkenone paleothermometry. Geochimica et Cosmochimica Acta $175,168-180$.

de Leeuw, J.W., van der Meer, F.W., Rijpstra, W.I.C., 1980. On the occurrence and structural identification of long chain unsaturated ketones and hydrocarbons in sediments. In: Douglas, A.D., Maxwell, J.R. (Eds.), Advances in Organic Geochemistry 1979. Pergamon, Oxford, pp. 2311-2317.

Ellegaard, M., Moestrup, Ø., Andersen, T.J., Lundholm, N., 2016. Long-term survival of haptophyte and prasinophyte resting stage in marine sediment. European Journal of Phycology 51, 328-337. 
Giordano, M., Prioretti, L. 2015. Sulphur and algae: metabolism, ecology and evolution. In: Borowitzka, M.A., Beardall, J., Raven, J.A. (Eds.), The Physiology of Microalgae. Springer, Dordrecht, The Netherlands, pp. 185-209.

Hastie, T., Tibshirani, R., Friedman, J., 2009. The Elements of Statistical Learning. Data Mining, Inference and Prediction, 2nd Ed. Springer.

Hayashi, M., van der Kamp, G., 2009. Groundwater-wetland ecosystem interaction in the semiarid glaciated plains of North America. Hydrogeology Journal 17, 203-214.

Hothorn, T., Zeileis, A., 2015. partykit: A modular toolkit for recursive partytioning in R. Journal of Machine Learning Research 16, 3905-3909.

Hou, J., Huang, Y., Zhao, J., Liu, Z., Colman, S., An, Z., 2016. Large Holocene summer temperature oscillations and impact on the peopling of the northeastern Tibetan Plateau. Geophysical Research Letters 43, 1323-1330.

Huguet, C., Fietz, S., Stockhecke, M., Sturm, M., Anselmetti, F.S., Rosell-Melé, A., 2011. Biomarker seasonality study in Lake Van, Turkey. Organic Geochemistry 42, 1289-1298.

Kaiser, J., van der Meer, M.T.J., Arz, H.W., 2017. Long-chain alkenones in Baltic Sea surface sediments: New insights. Organic Geochemistry 112, 93-104.

Korkonen, S.T., Ojala, A.E.K., Kosonen, E., Weckström, J., 2017. Seasonality of chrysophyte cyst and diatom assemblages in varved Lake Nautajärvi - implications for palaeolimnological studies. Journal of Limnology 76, 366-379.

Lampert, W., Sommer, U., 1997. Limnoecology: The Ecology of Lakes and Streams. Oxford University Press, Oxford, $382 \mathrm{pp}$.

Last, W.M., Ginn, F.M., 2005. Saline systems of the Great Plains of western Canada: an overview of the limnogeology and paleolimnology. Saline Systems 1, 1-38.

Leavitt, P.R., 1993. A review of factors that regulate carotenoid and chlorophyll deposition and fossil pigment abundance. Journal of Paleolimnology 9, 109-127.

Leavitt, P.R., Fritz, S.C., Anderson, N.J., Baker, P.A., Blenckner, T., Bunting, L., Catalan, J., Conley, D.J., Hobbs, W.O., Jeppesen, E., Korhola, A., McGowan, S., Rühland, K., Rusak, J.A., Simpson, G.L., 
Solovieva, N., Werne, J., 2009. Paleolimnological evidence of the effects on lakes of energy and mass transfer from climate and humans. Limnology and Oceanography 54, 2330-2348.

Li, J., Philp, R.P., Pu, F., Allen, J., 1996. Long-chain alkenones in Qinghai Lake sediments. Geochimica et Cosmochimica Acta 60, 235-241.

Liu, W.G., Liu, Z.H., Fu, M.Y., An, Z.H., 2008. Distribution of the $\mathrm{C}_{37}$ tetra-unsaturated alkenone in Lake Qinghai, China: a potential lake salinity indicator. Geochimica et Cosmochimica Acta 72, 988-997. Liu, W.G., Liu, Z.H., Wang, H.Y., He, Y.X., Wang, Z., Xu, L.M., 2011. Salinity control on long-chain alkenone distributions in lake surface waters and sediments of the northern Qinghai-Tibetan Plateau, China. Geochimica et Cosmochimica Acta 75, 1693-1703.

Longo, W.M., Dillon, J.T., Tarozo, R., Salacup, J.M., Huang, Y., 2013. Unprecedented separation of longchain alkenones from gas chromatography with a poly(trifluoropropylmethylsiloxane) stationary phase. Organic Geochemistry 65, 94-102.

Longo, W.M., Theroux, S., Giblin, A.E., Zheng, Y., Dillon, J.T., Huang, Y., 2016. Temperature calibration and phylogenetically distinct distributions for freshwater alkenones: Evidence from northern Alaskan lakes. Geochimica et Cosmochimica. Acta 180, 177-196.

Marlowe, I.T., Brassell, S.C., Eglinton, G., Green, J.C., 1984. Long-chain unsaturated ketones and esters in living algae and marine sediments. Organic Geochemistry 6, 135-141.

Marlowe, I.T., Brassell, S.C., Eglinton, G., Green, J.C., 1990. Long-chain alkenones and alkyl alkenoates and the fossil coccolith record of marine sediments. Chemical Geology 88, 349-375.

Michels, A., Laird, K.R., Wilson, S.E., Thomson, D., Leavitt, P.R., Oglesby, R.J., Cumming, B.F., 2007. Multidecadal to millennial-scale shifts in drought conditions on the Canadian prairies over the past six millennia: implications for future drought assessment. Global Change Biology 13, 1295-1307.

Müller, P.J., Kirst, G., Ruhland, G., von Storch, I., Rosell-Melé, A., 1998. Calibration of the alkenone paleotemperature index $\mathrm{U}_{37}^{\mathrm{K}^{\prime}}$ based on core-tops from the eastern South Atlantic and the global ocean $\left(60^{\circ} \mathrm{N}-60^{\circ} \mathrm{S}\right)$. Geochimica et Cosmochimica Acta 62, 1757-1772.

Nagelkerke, N.J.D., 1991. A note on a general definition of the coefficient of determination. Biometrika 78, 691-692. 
Oksanen, J., Blanchet, F.G., Friendly, M., Kindt, R., Legendre, P., McGlinn, D., Minchin, P.R., O'Hara,

R.B., Simpson, G.L., Solymos, P., Stevens, M.H.M., Szoecs, E., Wagner, H., 2017. vegan:

Community Ecology Package. R package version 2.4-3. https://CRAN.R-project.org/package=vegan

Pahnke, K., Sachs, J.P., 2006. Sea surface temperatures of southern midlatitudes 0-160 kyr B.P.

Paleoceanography 21, PA2003. DOI: 10.1029/2005PA001191.

Pearson, E.J., Juggins, S., Farrimond, P., 2008. Distribution and significance of long-chain alkenones as salinity and temperature indicators in Spanish saline lake sediments. Geochimica et Cosmochimica Acta 72, 4035-4046.

Pham, S.V., Leavitt, P.R., McGowan, S., Peres-Neto, P., 2008. Spatial variability of climate and land-use effects on lakes of the northern Great Plains. Limnology and Oceanography 53, 728-742.

Pham, S.V., Leavitt, P.R., McGowan, S., Wissel, B., Wassenaar, L.I., 2009. Spatial and temporal variability of prairie lake hydrology as revealed using stable isotopes of hydrogen and oxygen. Limnology and Oceanography 54, 101-118.

Prahl, F.G., Wakeham, S.G., 1987. Calibration of unsaturation patterns in long-chain ketone compositions for palaeotemperature assessment. Nature 330, 367-369.

Prahl, F.G., Muehlhausen, L.A., Zahnle, D.L., 1988. Further evaluation of long-chain alkenones as indicators of paleoceanographic conditions. Geochimica et Cosmochimica Acta 52, 2303-2310.

R Development Core Team, 2017. R: A language and environment for statistical computing. R Foundation for Statistical Computing, Vienna, Austria. https://www.R-project.org/.

Randlett, M.-E., Coolen, M.J.L., Stockhecke, M., Pickarski, N., Litt, T., Balkema, C., Kwiecien, O., Tomonaga, Y., Wehrli, B., Schubert, C.J., 2014. Alkenone distribution in Lake Van sediment over the last $270 \mathrm{ka}$ : influence of temperature and haptophyte species composition. Quaternary Science Reviews 104, 53-62.

Rontani, J.-F., Beker, B., Volkman, J.K., 2004. Regiospecific oxygenation of alkenones in the benthic haptophyte Chrysotila lamellosa Anand HAP 17. Phytochemistry 65, 3269-3278. 
Rosell-Melé, A., Eglinton, G., Pflaumann, U., Sarnthein, M., 1995. Atlantic core-top calibration of the $U_{37}^{K}$ index as a sea-surface palaeotemperature indicator. Geochimica et Cosmochimica Acta 59, 30993107.

Rosell-Melé, A., 1998. Interhemispheric appraisal of the value of alkenone indices as temperature and salinity proxies in high-latitude locations. Paleoceanography 13, 694-703.

Salmi, P., Salonen, K., 2016. Regular build-up of the spring phytoplankton maximum before ice-break in a boreal lake. Limnology and Oceanography 61, 240-253.

Schulz, H.M., Schöner, A., Emeis, K.C., 2000. Long-chain alkenone patterns in the Baltic Sea-an oceanfreshwater transition. Geochimica et Cosmochimica Acta 64, 469-477.

Sikes, E.L., Volkman, J.K., 1993. Calibration of alkenone unsaturation ratios $\left(\mathrm{U}_{37}^{\mathrm{K}^{\prime}}\right)$ for paleotemperature estimation in cold polar waters. Geochimica et Cosmochimica Acta 57, 1883-1889.

Sikes, E.L., Sicre, M.A., 2002. Relationship of the tetra-unsaturated $\mathrm{C}_{37}$ alkenone to salinity and temperature: implications for paleoproxy applications. Geochemistry, Geophysics, Geosystems 3, 111.

Song, M., Zhou, A., He, Y., Zhao, C., Wu, J., Zhao, Y., Liu, W., Liu, Z., 2016. Environmental controls on long-chain alkenone occurrence and compositional patterns in lacustrine sediments, northwestern China. Organic Geochemistry 91, 43-53.

Stainton, M.P., Capel, M.J., Armstrong, F.A.J., 1977. The Chemical Analysis of Freshwater. 2nd Ed. Environment Canada Miscellaneous Special Publication 25.

Sun, Q., Chu, G., Li, S., Lü, C., Zheng, M., 2004. Long-chain alkenones in sulfate lakes and its paleoclimatic implications. Chinese Science Bulletin 49, 2082-2086.

Sun, Q., Chu, G., Liu, G., Li, S., Wang, X., 2007. Calibration of alkenone unsaturation index with growth temperature for a lacustrine species, Chrysotila lamellosa (Haptophyceae). Organic Geochemistry $38,1226-1234$.

Takahashi, H., Kopriva, S., Giordano, M., Saito, K., Hell, R., 2011. Sulfur assimilation in photosynthetic organisms: Molecular functions and regulations of transporters and assimilatory enzymes. Annual Review of Plant Biology 62, 157-184. 
Taranu, Z.E., Gregory-Eaves, I., Steele, R.J., Beaulieu, M., Legendre, P., 2017. Predicting microcystin concentrations in lakes and reservoirs at a continental scale: A new framework for modelling an important health risk factor. Global Ecology and Biogeogeography 26, 625-637.

Theissen, K.M., Zinniker, D.A., Moldowan, J.M., Dunbar, R.B., Rowe, H.D., 2005. Pronounced occurrence of long-chain alkenones and dinosterol in a 25,000-year lipid molecular fossil record from Lake Titicaca, South America. Geochimica et Cosmochimica Acta 69, 623-636.

Theroux, S., D'Andrea, W.J., Toney, J.L., Amaral-Zettler, L., Huang, Y., 2010. Phylogenetic diversity and evolutionary relatedness of alkenone-producing haptophyte algae in lakes: Implications for continental paleotemperature reconstructions. Earth and Planetary Science Letters 300, 311-320.

Theroux, S., 2012. Diversity and Ecology of Lacustrine Haptophyte Algae: Implications for Paleothermometry. PhD Thesis, Brown University.

Theroux, S., Toney, J.L., Amaral-Zettler, L., Huang, Y., 2013. Production and temperature sensitivity of long chain alkenones in the cultured haptophyte Pseudoisochrysis paradoxa. Organic Geochemistry $62,68-73$.

Thiel, V., Jenisch, A., Landmann, G., Reimer, A., Michaelis, W., 1997. Unusual distributions of long-chain alkenones and tetrahymanol from the highly alkaline Lake Van, Turkey. Geochimica et Cosmochimica Acta 61, 2053-2064.

Toney, J.L., Huang, Y., Fritz, S.C., Baker, P.A., Grimm, E., Nyren, P., 2010. Climatic and environmental controls on the occurrence and distributions of long-chain alkenones in lakes of the interior United States. Geochimica et Cosmochimica Acta 74, 1563-1578.

Toney, J.L., Leavitt, P.R., Huang, Y., 2011. Alkenones are common in prairie lakes of interior Canada. Organic Geochemistry 42, 707-712.

Toney, J.L., Theroux, S., Andersen, R.A., Coleman, A., Amaral-Zettler, L., Huang, Y., 2012. Culturing of the first 37:4 predominant lacustrine haptophyte: Geochemical, biochemical, and genetic implications. Geochimica et Cosmochimica Acta 78, 51-64.

Volkman, J.K., Eglinton, G., Corner, E.D.S., Forsberg, T.E.V., 1980. Long-chain alkenes and alkenones in the marine coccolithophorid Emiliania huxleyi. Phytochemistry 19, 2619-2622. 
Volkman, J.K., Barrett, S.M., Blackburn, S.I., Sikes, E.L., 1995. Alkenones in Gephyrocapsa oceanica:

Implications for studies of paleoclimate. Geochimica et Cosmochimica Acta 59, 513-520.

Wetzel, R.G, 2001. Limnology. Lake and River Ecosystems. 3rd Ed. Academic Press, 1006 pp.

Whittingham, M.J., Stephens, P.A., Bradbury, R.B., Freckleton, R.P., 2006. Why do we still use stepwise modelling in ecology and behaviour? The Journal of Animal Ecology 75, 1182-1189.

Zhao, J., An, C., Longo, W.M., Dillon, J.T., Zhao, Y., Shi, C., Chen, Y., Huang, Y., 2014. Occurrence of extended chain length $\mathrm{C}_{41}$ and $\mathrm{C}_{42}$ alkenones in hypersaline lakes. Organic Geochemistry 75, 48-53.

Zheng, Y., Huang, Y., Andersen, R.A., Amaral-Zettler, L.A., 2016. Excluding the di-unsaturated alkenone in the $U_{37}^{K}$ index strengthens temperature correlation for the common lacustrine and brackish-water haptophytes. Geochimica et Cosmochimica Acta 175, 36-46.

Zink, K.-G., Leythaeuser, D., Melkonian, M., Schwark, L., 2001. Temperature dependency of long-chain alkenone distributions in recent to fossil limnic sediments and in lake waters. Geochimica et Cosmochimica Acta 65, 253-265.

Zuur, A., A.A.S., Ieno, E., 2012. Zero inflated model and generalized linear mixed models with R. Highland Statistics Ltd.

\section{Figure captions}

Fig. 1. Map of the southern Saskatchewan, Canada showing the location of the studied lakes. Individual lakes are plotted as “+” (no LCAs) or circles scaled to LCA concentration ( $\mu \mathrm{g} / \mathrm{gTOC})$. The different LCA profiles found in this study are indicated by a colour code (white: high $\% \mathrm{C}_{37: 4}$; grey: $\mathrm{C}_{37: 3}$-dominated; black: $\mathrm{C}_{38}$-dominated).

Fig. 2. Signature sedimentary LCA profiles for the Canadian lakes. The profile with high (> 60\%) $\% \mathrm{C}_{37: 4}$ (A) is observed in the great majority of the studied lakes, while the $\mathrm{C}_{37: 3}$-dominated (B) and $\mathrm{C}_{38}$-dominated (C) profiles are only found in five lakes and a single lake, respectively. Four freshwater/oligohaline lakes also exhibit profile typical of Group I haptophyte (D), with the presence of tri-unsaturated isomers. 
Fig. 3. Probability of LCA occurrence, showing (A)-(D) logistic (binomial model) regression plots, (E) mosaic plot of LCA occurrence vs thermal regime for raw data (left) and model fitted values (right), and (F) the shared and independent fraction of variance explained by each predictor in the final LCA model. Shaded areas show 95\% CIs (confidence intervals) and ticks on the upper and lower axes indicate original observations. Statistics $\left(\mathrm{r}^{2}, p\right.$ value) for the regression plots (A)-(D) are presented in the Supplementary Table S2.

Fig. 4. Classification tree of LCA occurrence. Splits indicate thresholds for occurrence at particular environmental values. Bars at each node show proportions of observations where LCAs are present (dark grey) or absent (light grey).

Fig. 5. LCA concentration as a function of selected significant environmental variables, showing (A) $-(\mathrm{C})$ scatter plots and fitted regression lines (log-normal model), (D) boxplot of LCA concentration as a function of thermal regime, and $(\mathrm{E})$ the shared and independent fraction of variance explained by each predictor in the final LCA model. Shaded areas show 95\% CIs (confidence intervals) and ticks on the upper and lower axes indicate original observations. Error bars in (D) indicate model fitted values and $95 \%$ CIs. Statistics $\left(\mathrm{r}^{2}\right.$, $p$ value) for the scatter plots (A)-(C) are presented in the Supplementary Table S2.

Fig. 6. Regression tree of LCA occurrence. Splits indicate thresholds for occurrence at particular environmental values. Boxplots summarise LCA concentration for observations in that node. Note that boxplot scale is in $\log 10$ units ( $\log 10$ of LCA concentration in $\mu \mathrm{g} / \mathrm{gTOC})$. 
Figure 1 


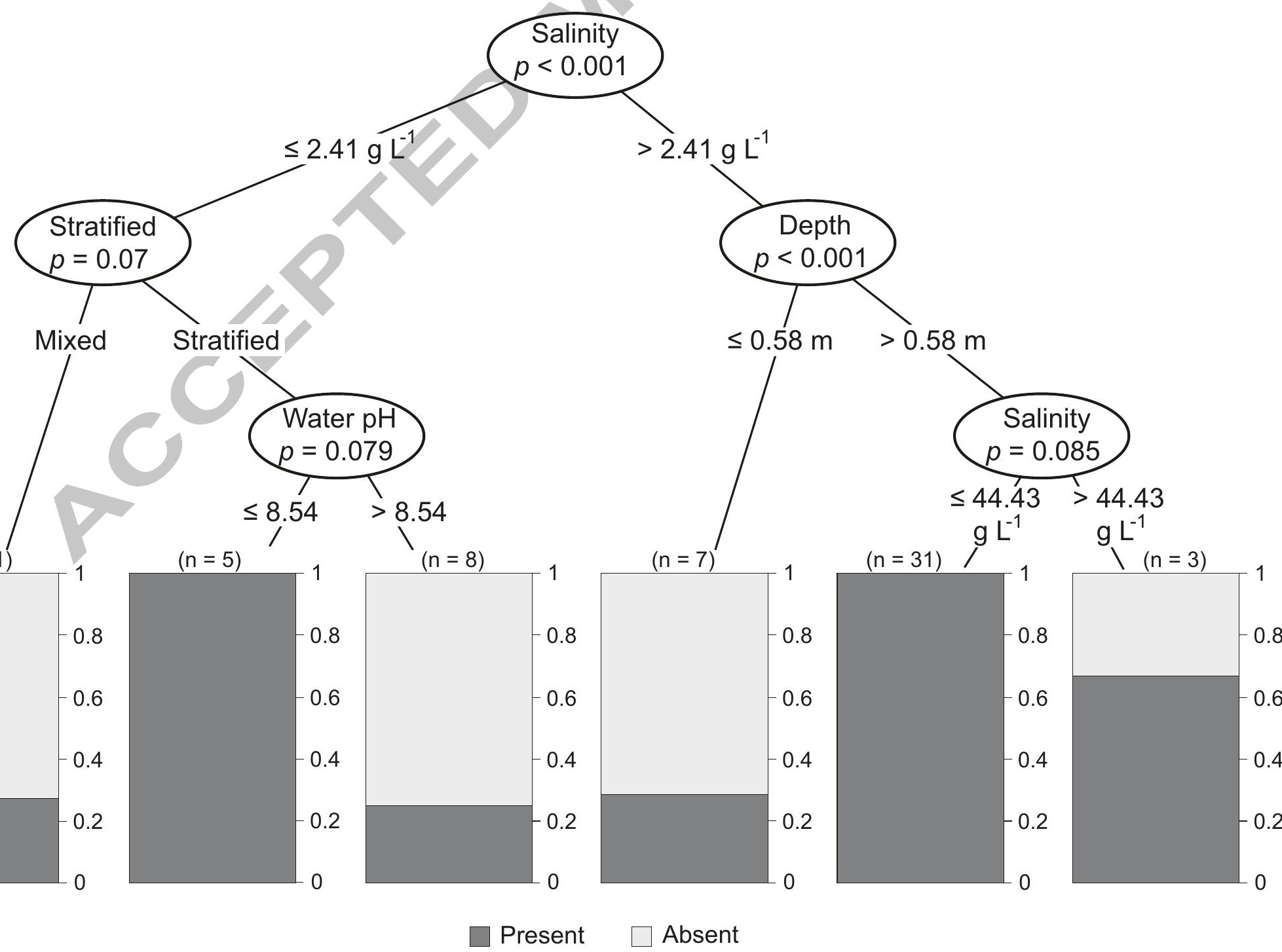




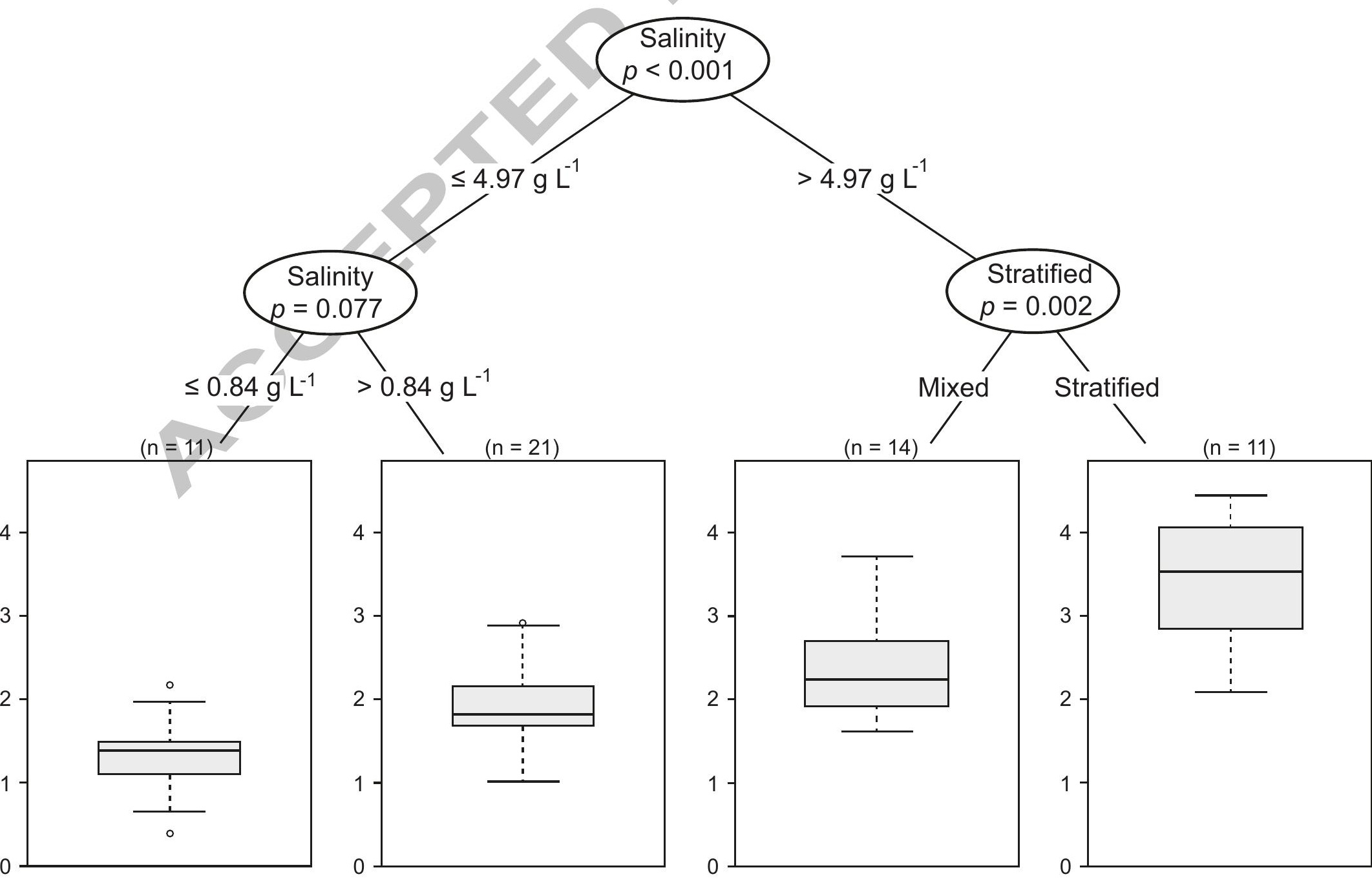


ACCEPTED MANUSCRIPT

\begin{tabular}{|c|c|c|c|c|c|c|c|c|c|c|c|c|c|c|c|c|c|}
\hline Lake Name & $\begin{array}{l}\text { Lat. } \\
\left({ }^{\circ} \mathrm{N}\right)\end{array}$ & $\begin{array}{l}\text { Long. } \\
\left({ }^{\circ} \mathrm{W}\right)\end{array}$ & $\begin{array}{c}\text { Stratif. } \\
\text { a }\end{array}$ & $\begin{array}{l}\text { Depth } \\
(\mathrm{m})\end{array}$ & $\begin{array}{c}\text { Salinity } \\
(\mathrm{g} / \mathrm{L})\end{array}$ & $\begin{array}{c}\text { Temp. } \\
\left({ }^{\circ} \mathrm{C}\right)\end{array}$ & $\mathrm{pH}$ & $\underset{\mathrm{b}}{\mathrm{SCR}}$ & $\begin{array}{c}\text { TOC } \\
(\%)\end{array}$ & $\begin{array}{c}\text { LCAs } \\
(\mu \mathrm{g} / \mathrm{gTOC})\end{array}$ & $\begin{array}{c}\text { LCAs } \\
(\mu \mathrm{g} / \mathrm{gsed})\end{array}$ & $\begin{array}{c}\% \mathrm{C}_{37: 4} \\
\mathrm{c}\end{array}$ & $\begin{array}{c}\mathrm{C}_{37} / \mathrm{C}_{38} \\
\mathrm{~d}\end{array}$ & $\underset{\mathrm{e}}{\mathrm{RIK}_{37}}$ & $\underset{\mathrm{f}}{\mathrm{U}}$ & $\begin{array}{c}\mathrm{U}_{37}^{\mathrm{K}^{\prime}} \\
\mathrm{g}\end{array}$ & $\begin{array}{c}\mathrm{U}_{37}^{\mathrm{K}^{\prime \prime}} \\
\mathrm{h}\end{array}$ \\
\hline \multicolumn{18}{|l|}{ LCAs present } \\
\hline Alsask & 51.34 & 109.88 & $\mathrm{~N}$ & 3.2 & 74.8 & 19.6 & 9.35 & 17.7 & 3.21 & 135 & 4.33 & 29.6 & 1.59 & 1.00 & -0.18 & 0.16 & 0.67 \\
\hline Antelope & 50.28 & 108.39 & $\mathrm{~N}$ & 7.7 & 7.87 & 21.4 & 9.40 & 91.1 & 7.89 & 799 & 63.0 & 70.5 & 5.17 & 1.00 & -0.66 & 0.17 & 0.26 \\
\hline Arthur & 52.56 & 105.44 & $\mathrm{~T}, \mathrm{M}$ & 6.7 & 8.29 & 15.1 & 8.88 & N.D. & 8.71 & 3296 & 287 & 69.9 & 2.83 & 1.00 & -0.64 & 0.19 & 0.26 \\
\hline Bitter & 50.10 & 109.79 & $\mathrm{~N}$ & 0.9 & 15.1 & 19.1 & 8.69 & 510 & 2.15 & 609 & 13.1 & 46.9 & 1.28 & 1.00 & -0.33 & 0.25 & 0.46 \\
\hline Blackstrap & 51.79 & 106.44 & $\mathrm{~N}$ & 7.9 & 0.43 & 19.1 & 8.84 & 47.2 & 8.22 & 26.9 & 2.21 & 52.0 & 2.59 & 1.00 & -0.46 & 0.12 & 0.45 \\
\hline Bullkin & 49.25 & 105.07 & $\mathrm{~N}$ & 0.7 & 2.01 & 19.4 & 9.06 & 25.5 & 1.24 & 49.8 & 0.62 & 76.5 & 2.57 & 1.00 & -0.70 & 0.26 & 0.18 \\
\hline Charron & 52.40 & 104.31 & $\mathrm{~T}$ & 8.8 & 4.9 & 16.9 & 10.5 & 125 & 14.6 & 927 & 135 & 58.2 & 2.82 & 1.00 & -0.50 & 0.19 & 0.37 \\
\hline Clair & 51.99 & 104.06 & $\mathrm{~N}$ & 3.0 & 0.78 & 22.1 & 9.20 & 25.3 & 8.33 & 23.9 & 2.00 & 55.8 & N.D. & 1.00 & -0.51 & 0.11 & 0.41 \\
\hline Coldspring & 52.35 & 108.59 & $\mathrm{~N}$ & 2.4 & 5.86 & 19.1 & 8.62 & 88.3 & 5.03 & 178 & 8.95 & 73.0 & 3.50 & 1.00 & -0.62 & 0.40 & 0.18 \\
\hline Deadmoose & 52.30 & 105.17 & $\mathrm{~T}, \mathrm{M}$ & 15.1 & 12.3 & 12.6 & 8.87 & 99.8 & 8.24 & 383 & 31.6 & 53.3 & 1.73 & 1.00 & -0.41 & 0.27 & 0.39 \\
\hline Dewey & 50.58 & 107.07 & $\mathrm{~N}$ & 2.3 & 8.54 & 18.8 & 8.40 & 216 & 7.87 & 144 & 11.4 & 38.2 & 2.14 & 1.00 & -0.26 & 0.19 & 0.57 \\
\hline Diefenbaker & 51.10 & 106.62 & $\mathrm{~N}$ & 28.5 & 0.22 & 19.3 & 8.27 & 19.8 & 3.11 & 87.6 & 2.72 & 52.1 & 1.38 & 0.47 & -0.48 & 0.17 & 0.28 \\
\hline Eaglehill & 52.36 & 108.97 & $\mathrm{~N}$ & 1.1 & 2.64 & 18.7 & 9.03 & 1.92 & 4.61 & 37.5 & 1.73 & 79.5 & N.D. & 1.00 & -0.76 & 0.17 & 0.18 \\
\hline Farewell & 52.47 & 109.38 & $\mathrm{~N}$ & 0.4 & 3.57 & 22.4 & 9.40 & 13.4 & 1.45 & 92.4 & 1.34 & 45.5 & N.D. & 1.00 & -0.34 & 0.22 & 0.48 \\
\hline Fife & 49.22 & 105.86 & $\mathrm{~N}$ & 2.4 & 1.47 & 19.9 & 9.06 & 4.31 & 2.88 & 10.4 & 0.30 & 72.4 & 2.56 & 1.00 & -0.63 & 0.33 & 0.20 \\
\hline Fishing & 51.82 & 103.47 & $\mathrm{~N}$ & 11.5 & 1.31 & 20.1 & 9.17 & 66.2 & 12.3 & 39.9 & 4.90 & 50.9 & 1.29 & 0.44 & -0.45 & 0.23 & 0.27 \\
\hline Freefight & 50.40 & 109.11 & $\mathrm{~T}, \mathrm{M}$ & 15 & 40.8 & 17.6 & 8.33 & 89.2 & 1.14 & 135 & 1.54 & 46.3 & 1.63 & 1.00 & -0.29 & 0.32 & 0.44 \\
\hline Greenwater & 52.52 & 103.50 & $\mathrm{~N}$ & 7.5 & 0.33 & 20.1 & 8.23 & 153 & 17.2 & 2.48 & 0.43 & 43.3 & N.D. & 1.00 & -0.23 & 0.36 & 0.46 \\
\hline Humboldt & 52.14 & 105.12 & $\mathrm{~N}$ & 6.3 & 0.84 & 20.8 & 9.13 & 31.8 & 9.89 & 23.7 & 2.34 & 55.5 & 7.05 & 1.00 & -0.53 & 0.06 & 0.43 \\
\hline Junction & 49.96 & 109.51 & $\mathrm{~N}$ & 9.0 & 0.66 & 19.3 & 8.92 & 57.9 & 3.49 & 148 & 5.17 & N.D. & N.D. & 1.00 & N.D. & N.D. & N.D. \\
\hline Katepwa & 50.71 & 103.65 & $\mathrm{~T}$ & 22.4 & 0.8 & 15.6 & 8.29 & 237 & 6.38 & 14.7 & 0.94 & 47.7 & 6.35 & 1.00 & -0.43 & 0.09 & 0.50 \\
\hline Kenosee & 49.82 & 102.30 & $\mathrm{~N}$ & 7.4 & 1.32 & 19.1 & 8.79 & 26.6 & 8.92 & 82.7 & 7.38 & 62.2 & 6.33 & 1.00 & -0.59 & 0.08 & 0.36 \\
\hline L. Manitou & 51.74 & 105.52 & $\mathrm{~N}$ & 6.7 & 44.4 & 19.6 & 9.15 & 475 & 13.1 & 5063 & 662 & 55.6 & 2.24 & 1.00 & -0.46 & 0.21 & 0.39 \\
\hline Lenore SB & 52.45 & 105.00 & $\mathrm{~T}$ & 9.1 & 4.43 & 21.1 & 9.38 & 39.9 & 16.1 & 143 & 22.9 & 39.4 & 0.88 & 0.54 & -0.29 & 0.28 & 0.41 \\
\hline Little Manitou & 52.62 & 109.62 & $\mathrm{~N}$ & 3.8 & 3.62 & 21.5 & 9.19 & 4.56 & 13.1 & 50.1 & 6.55 & 48.7 & 4.00 & 0.49 & -0.43 & 0.22 & 0.31 \\
\hline Luck & 51.07 & 107.10 & $\mathrm{~N}$ & 0.8 & 4.55 & 18.2 & 9.64 & 47.7 & 3.00 & 27.5 & 1.91 & 66.7 & 1.99 & 1.00 & -0.57 & 0.28 & 0.26 \\
\hline Madge & 51.65 & 101.63 & $\mathrm{~N}$ & 12.3 & 0.38 & 19.4 & 8.36 & 235 & 8.61 & 11.0 & 0.95 & 51.3 & 1.66 & 1.00 & -0.42 & 0.20 & 0.43 \\
\hline Manitou & 52.76 & 109.75 & $\mathrm{~T}$ & 15.9 & 29.1 & 8.75 & 9.56 & 13.2 & 8.37 & 27,575 & 2308 & 66.4 & 2.14 & 1.00 & -0.59 & 0.22 & 0.28 \\
\hline Mason & 50.36 & 109.35 & $\mathrm{~N}$ & 1.9 & 4.97 & 19.3 & 9.25 & 21.2 & 5.02 & 12.4 & 0.62 & 72.3 & 3.04 & 1.00 & -0.61 & 0.41 & 0.19 \\
\hline
\end{tabular}


ACCEPTED MANUSCRIPT

\begin{tabular}{|c|c|c|c|c|c|c|c|c|c|c|c|c|c|c|c|c|c|}
\hline McLean & 52.62 & 109.37 & $\mathrm{~N}$ & 6.5 & 46.2 & 21.1 & 9.27 & 552 & 1.71 & 77.9 & 1.33 & 44.2 & 1.63 & 1.00 & -0.39 & 0.10 & 0.53 \\
\hline Middle & 52.56 & 105.19 & $\mathrm{~T}$ & 10.0 & 5.14 & 16.8 & 8.93 & 88.7 & 6.40 & 11,522 & 737 & 72.9 & 1.29 & 1.00 & -0.68 & 0.18 & 0.23 \\
\hline Montague & 49.47 & 105.83 & $\mathrm{~N}$ & 1.4 & 1.07 & 19.6 & 9.06 & 15.6 & 1.38 & 135 & 1.87 & 72.9 & 2.58 & 1.00 & -0.67 & 0.22 & 0.22 \\
\hline Old Wives & 50.10 & 105.99 & $\mathrm{~N}$ & 1.7 & 1.51 & 18.9 & 9.29 & 6.78 & 0.10 & 17.9 & 0.02 & N.D. & N.D. & 1.00 & N.D. & N.D. & 0.33 \\
\hline Opuntia & 51.81 & 108.57 & $\mathrm{~N}$ & 1.6 & 2.98 & 21.4 & 9.02 & 35.6 & 2.41 & 603 & 14.5 & 75.8 & 7.73 & 1.00 & -0.73 & 0.12 & 0.22 \\
\hline Porter & 52.19 & 106.29 & $\mathrm{~N}$ & 4.0 & 2.78 & 19.2 & 8.48 & 5.31 & 4.62 & 819 & 37.8 & 66.9 & 2.56 & 1.00 & -0.59 & 0.25 & 0.27 \\
\hline Quill & 51.86 & 104.37 & $\mathrm{~N}$ & 6.4 & 7.29 & 19.1 & 8.78 & 189 & 8.05 & 383 & 30.8 & 65.1 & 4.13 & 1.00 & -0.51 & 0.41 & 0.24 \\
\hline Rabbit & 52.61 & 107.02 & $\mathrm{~S}$ & 6.5 & 4.23 & 19.3 & 9.21 & 80.5 & 11.8 & 72.6 & 8.60 & 70.0 & 4.49 & 1.00 & -0.64 & 0.19 & 0.26 \\
\hline Redberry & 52.62 & 107.02 & $\mathrm{~T}$ & 14.8 & 8.61 & 12.1 & 9.09 & 22.8 & 4.40 & 11,143 & 490 & 69.4 & 2.15 & 1.00 & -0.64 & 0.16 & 0.27 \\
\hline Reesor & 49.66 & 110.11 & $\mathrm{~N}$ & 5.0 & 0.14 & 18.9 & 8.48 & N.D. & 9.15 & 10.3 & 0.41 & 72.5 & 1.64 & 1.00 & N.D. & N.D. & 0.28 \\
\hline Richmond & 52.01 & 108.02 & $\mathrm{~N}$ & 1.8 & 10.0 & 18.8 & 8.62 & 3634 & 12.1 & 73.3 & 8.88 & 34.1 & 0.38 & 1.00 & -0.24 & 0.16 & 0.62 \\
\hline Shannon & 52.65 & 105.43 & $\mathrm{~T}$ & 11.2 & 1.67 & 15.8 & 9.06 & 53.4 & 9.53 & 445 & 42.4 & 61.6 & 2.80 & 1.00 & -0.55 & 0.18 & 0.34 \\
\hline Shoe & 49.72 & 105.36 & $\mathrm{~N}$ & 3.8 & 25.1 & 19.9 & 8.90 & 266 & 6.94 & 110 & 7.64 & 41.4 & 1.71 & 1.00 & -0.28 & 0.23 & 0.52 \\
\hline Sink & 52.44 & 109.19 & $\mathrm{~N}$ & 2.8 & 2.83 & 20.9 & 8.66 & 12.2 & 14.7 & 175 & 25.8 & 79.2 & 2.78 & 1.00 & -0.76 & 0.18 & 0.18 \\
\hline Snakehole & 50.50 & 108.49 & $\mathrm{~N}$ & 2.4 & 50.2 & 23.2 & 8.96 & N.D. & 4.16 & 191 & 7.96 & 45.6 & 1.97 & 1.00 & -0.38 & 0.13 & 0.51 \\
\hline Springwater & 52.01 & 108.39 & $\mathrm{~N}$ & 3.1 & 6.56 & 22.4 & 8.62 & 47.5 & 4.40 & 797 & 35.1 & 37.5 & 2.17 & 1.00 & -0.21 & 0.26 & 0.55 \\
\hline Success & 50.49 & 108.02 & $\mathrm{~T}, \mathrm{M}$ & 17.4 & 34.9 & 11.3 & 8.62 & 43.4 & 4.66 & 94.2 & 4.39 & 45.1 & 1.50 & 1.00 & -0.30 & 0.28 & 0.47 \\
\hline Sufferin & 52.64 & 109.90 & $\mathrm{~N}$ & 8 & 0.22 & 19.7 & 8.18 & N.D. & 12.7 & 31.8 & 4.03 & 37.3 & 1.64 & 1.00 & -0.28 & 0.14 & 0.59 \\
\hline Summercove & 49.32 & 107.04 & $\mathrm{~N}$ & 5 & 0.98 & 20.0 & 8.97 & 13.1 & 5.24 & 31.5 & 1.65 & 67.8 & 6.97 & 1.00 & -0.65 & 0.09 & 0.30 \\
\hline Sunny & 52.02 & 108.52 & $\mathrm{~T}, \mathrm{M}$ & 15 & 11.6 & 8.63 & 8.50 & 43.3 & 7.94 & 3143 & 249 & 63.5 & 2.27 & 1.00 & -0.56 & 0.21 & 0.31 \\
\hline Tramping & 52.03 & 108.82 & $\mathrm{~N}$ & 3.4 & 11.6 & 23.7 & 9.14 & 121 & 12.6 & 99.3 & 12.5 & 67.3 & 0.49 & 1.00 & -0.63 & 0.13 & 0.30 \\
\hline Unknown 1 & 51.55 & 104.27 & $\mathrm{~N}$ & 1.8 & 1.27 & 21.7 & 8.73 & N.D. & 5.24 & 53.3 & 2.79 & 69.8 & 0.93 & 1.00 & -0.60 & 0.32 & 0.23 \\
\hline Van Scoy & 52.08 & 107.55 & $\mathrm{~N}$ & 0.9 & 6.44 & 20.6 & 8.82 & N.D. & 7.03 & 17.6 & 1.24 & 28.9 & 1.40 & 1.00 & -0.05 & 0.33 & 0.62 \\
\hline Wakaw & 52.66 & 105.60 & $\mathrm{~T}$ & 10.3 & 1.5 & 19.7 & 8.54 & 5.06 & 12.2 & 132 & 16.1 & 68.6 & N.D. & 1.00 & -0.67 & 0.05 & 0.30 \\
\hline Waldsea & 52.26 & 105.18 & $\mathrm{~T}, \mathrm{M}$ & 19.9 & 12.8 & 9.85 & 8.45 & 165 & 8.51 & 24,494 & 2084 & 71.9 & 2.81 & 1.00 & -0.67 & 0.16 & 0.25 \\
\hline White Heron & 51.89 & 109.05 & $\mathrm{~N}$ & 0.8 & 1.88 & 21.9 & 8.94 & 12.7 & 6.46 & 29.5 & 1.91 & 67.7 & N.D. & 1.00 & -0.62 & 0.17 & 0.28 \\
\hline Willow Bunch & 49.45 & 105.46 & $\mathrm{~N}$ & 1.1 & 2.58 & 21.1 & 9.16 & 19.1 & 1.30 & 108 & 1.40 & 76.8 & 3.37 & 1.00 & -0.71 & 0.27 & 0.18 \\
\hline Wolverine & 52.03 & 105.22 & $\mathrm{~N}$ & 3.1 & 0.8 & 21.2 & 8.93 & 2.05 & 12.5 & 21.2 & 2.65 & 76.9 & 4.31 & 1.00 & -0.67 & 0.44 & 0.14 \\
\hline $\mathrm{X} 5$ & 52.67 & 110.08 & $\mathrm{~T}$ & 4.1 & 13.6 & 17.9 & 9.04 & 20.8 & 12.2 & 6064 & 741 & 65.1 & 2.91 & 1.00 & -0.59 & 0.18 & 0.31 \\
\hline
\end{tabular}

LCAs absent

$\begin{array}{lll}\text { Adrian } & 49.69 & 102.87 \\ \text { Alioth } & 52.51 & 109.55\end{array}$

$\begin{array}{llllllll}\mathrm{N} & 1.2 & 0.79 & 19.8 & 9.13 & 1.98 & 5.37 & \mathrm{x}^{\mathrm{i}} \\ \mathrm{N} & 0.6 & 13.9 & 21.2 & 10.3 & 179 & 9.14 & \mathrm{x}\end{array}$


ACCEPTED MANUSCRIPT

\begin{tabular}{|c|c|c|c|c|c|c|c|c|c|c|c|c|c|c|c|c|}
\hline Annie Laurie & 51.97 & 102.67 & $\mathrm{~N}$ & 1.3 & 0.25 & 22.1 & 8.78 & 23.3 & 20.0 & $\mathrm{x}$ & $\mathrm{x}$ & $\mathrm{x}$ & $\mathrm{x}$ & $\mathrm{x}$ & $\mathrm{x}$ & $\mathrm{x}$ \\
\hline Barber & 51.37 & 107.66 & $\mathrm{~N}$ & 1.6 & 1.26 & 20.4 & 8.57 & 34.1 & 3.87 & $\mathrm{x}$ & $\mathrm{x}$ & $\mathrm{x}$ & $\mathrm{x}$ & $\mathrm{x}$ & $\mathrm{x}$ & $\mathrm{x}$ \\
\hline Buffalo Pound & 50.61 & 105.43 & $\mathrm{~N}$ & 4.1 & 0.31 & 22.2 & 8.85 & 1.27 & 4.94 & $\mathrm{x}$ & $\mathrm{x}$ & $\mathrm{x}$ & $\mathrm{x}$ & $\mathrm{x}$ & $\mathrm{x}$ & $\mathrm{x}$ \\
\hline Chapleau & 50.18 & 103.34 & $\mathrm{~N}$ & 1.4 & 0.41 & 22.1 & 9.00 & 15.3 & 9.75 & $\mathrm{x}$ & $\mathrm{x}$ & $\mathrm{x}$ & $\mathrm{x}$ & $\mathrm{x}$ & $\mathrm{x}$ & $\mathrm{x}$ \\
\hline Clearwater & 50.87 & 107.93 & $\mathrm{~N}$ & 7.0 & 0.68 & 19.1 & 9.18 & 15.8 & 9.27 & $\mathrm{x}$ & $\mathrm{x}$ & $\mathrm{x}$ & $\mathrm{x}$ & $\mathrm{x}$ & $\mathrm{x}$ & $\mathrm{x}$ \\
\hline Crooked & 50.61 & 102.72 & $\mathrm{~N}$ & 10.2 & 0.82 & 21.0 & 8.72 & 49.8 & 5.70 & $\mathrm{x}$ & $\mathrm{x}$ & $\mathrm{x}$ & $\mathrm{x}$ & $\mathrm{x}$ & $\mathrm{x}$ & $\mathrm{x}$ \\
\hline Cutbank & 50.53 & 107.00 & $\mathrm{~S}$ & 2.4 & 2.41 & 20.4 & 9.13 & 23.1 & 5.87 & $\mathrm{x}$ & $\mathrm{x}$ & $\mathrm{x}$ & $\mathrm{x}$ & $\mathrm{x}$ & $\mathrm{x}$ & $\mathrm{x}$ \\
\hline Cypress & 49.47 & 109.47 & $\mathrm{~N}$ & 5.6 & 0.3 & 19.1 & 8.82 & 115 & 2.85 & $\mathrm{x}$ & $\mathrm{x}$ & $\mathrm{x}$ & $\mathrm{x}$ & $\mathrm{x}$ & $\mathrm{x}$ & $\mathrm{x}$ \\
\hline Deep & 50.42 & 103.68 & $\mathrm{~N}$ & 2.2 & 1.53 & 21.8 & 8.88 & 62.9 & 6.56 & $\mathrm{x}$ & $\mathrm{x}$ & $\mathrm{x}$ & $\mathrm{x}$ & $\mathrm{x}$ & $\mathrm{x}$ & $\mathrm{x}$ \\
\hline Edouard & 52.38 & 104.35 & $\mathrm{~N}$ & 5.6 & 0.34 & 19.9 & 11.1 & 98.6 & 13.4 & $\mathrm{x}$ & $\mathrm{x}$ & $\mathrm{x}$ & $\mathrm{x}$ & $\mathrm{x}$ & $\mathrm{x}$ & $\mathrm{x}$ \\
\hline Elkwater & 49.67 & 110.29 & $\mathrm{~N}$ & 7.9 & 0.18 & 18.7 & 8.65 & 67.6 & 4.25 & $\mathrm{x}$ & $\mathrm{x}$ & $\mathrm{x}$ & $\mathrm{x}$ & $\mathrm{x}$ & $\mathrm{x}$ & $\mathrm{x}$ \\
\hline Eyebrow & 50.96 & 106.19 & $\mathrm{~N}$ & 0.9 & 0.21 & 17.9 & 8.36 & N.D. & 1.34 & $\mathrm{x}$ & $\mathrm{x}$ & $\mathrm{x}$ & $\mathrm{x}$ & $\mathrm{x}$ & $\mathrm{x}$ & $\mathrm{x}$ \\
\hline Good Spirt & 51.55 & 102.67 & $\mathrm{~S}$ & 5.2 & 0.47 & 19.8 & 8.62 & 1.22 & 11.2 & $\mathrm{x}$ & $\mathrm{x}$ & $\mathrm{x}$ & $\mathrm{x}$ & $\mathrm{x}$ & $\mathrm{x}$ & $\mathrm{x}$ \\
\hline Gouverneur & 49.76 & 107.65 & $\mathrm{~N}$ & 7.2 & 1.38 & 19.8 & 8.73 & 35.9 & 2.37 & $\mathrm{x}$ & $\mathrm{x}$ & $\mathrm{x}$ & $\mathrm{x}$ & $\mathrm{x}$ & $\mathrm{x}$ & $\mathrm{x}$ \\
\hline Grassy & 51.24 & 104.63 & $\mathrm{~N}$ & 2.0 & 0.64 & 21.2 & 8.98 & 9.40 & 12.6 & $\mathrm{x}$ & $\mathrm{x}$ & $\mathrm{x}$ & $\mathrm{x}$ & $\mathrm{x}$ & $\mathrm{x}$ & $\mathrm{x}$ \\
\hline Gull & 50.11 & 108.50 & $\mathrm{~N}$ & 5.0 & 2.04 & 20.1 & 8.96 & 38.3 & N.D. & $\mathrm{x}$ & $\mathrm{x}$ & $\mathrm{x}$ & $\mathrm{x}$ & $\mathrm{x}$ & $\mathrm{x}$ & $\mathrm{x}$ \\
\hline Handsome & 50.49 & 107.38 & $\mathrm{~N}$ & 1.9 & 2.19 & 18.4 & 9.04 & 28.1 & 6.89 & $\mathrm{x}$ & $\mathrm{x}$ & $\mathrm{x}$ & $\mathrm{x}$ & $\mathrm{x}$ & $\mathrm{x}$ & $\mathrm{x}$ \\
\hline Harris & 49.82 & 109.50 & $\mathrm{~N}$ & 5.1 & 0.35 & 18.9 & 8.83 & 133 & 0.86 & $\mathrm{x}$ & $\mathrm{x}$ & $\mathrm{x}$ & $\mathrm{x}$ & $\mathrm{x}$ & $\mathrm{x}$ & $\mathrm{x}$ \\
\hline Horse & 51.39 & 103.56 & $\mathrm{~N}$ & 3.3 & 0.72 & 20.7 & 8.78 & 8.20 & 22.1 & $\mathrm{x}$ & $\mathrm{x}$ & $\mathrm{x}$ & $\mathrm{x}$ & $\mathrm{x}$ & $\mathrm{x}$ & $\mathrm{x}$ \\
\hline Island & 49.13 & 108.23 & $\mathrm{~N}$ & 2.0 & 0.18 & 21.7 & 8.87 & 7.31 & 6.62 & $\mathrm{x}$ & $\mathrm{x}$ & $\mathrm{x}$ & $\mathrm{x}$ & $\mathrm{x}$ & $\mathrm{x}$ & $\mathrm{x}$ \\
\hline Kindersley & 51.42 & 109.10 & $\mathrm{~N}$ & 1.6 & 0.42 & 17.6 & 9.66 & 37.7 & 2.02 & $\mathrm{x}$ & $\mathrm{x}$ & $\mathrm{x}$ & $\mathrm{x}$ & $\mathrm{x}$ & $\mathrm{x}$ & $\mathrm{x}$ \\
\hline Kipabiskau & 52.57 & 104.18 & $\mathrm{~N}$ & 6.8 & 0.78 & 21.7 & 8.90 & N.D. & 16.6 & $\mathrm{x}$ & $\mathrm{x}$ & $\mathrm{x}$ & $\mathrm{x}$ & $\mathrm{x}$ & $\mathrm{x}$ & $\mathrm{x}$ \\
\hline Lac Pelletier & 49.99 & 107.94 & $\mathrm{~N}$ & 8.8 & 0.41 & 20.9 & 9.46 & 1.04 & 12.1 & $\mathrm{x}$ & $\mathrm{x}$ & $\mathrm{x}$ & $\mathrm{x}$ & $\mathrm{x}$ & $\mathrm{x}$ & $\mathrm{x}$ \\
\hline Last Mountain & 51.10 & 105.26 & $\mathrm{~N}$ & 18.5 & 1.05 & 19.2 & 8.84 & 1.80 & 9.25 & $\mathrm{x}$ & $\mathrm{x}$ & $\mathrm{x}$ & $\mathrm{x}$ & $\mathrm{x}$ & $\mathrm{x}$ & $\mathrm{x}$ \\
\hline Lenore & 52.51 & 104.97 & $\mathrm{~T}$ & 10.1 & 2.26 & 17.7 & 8.97 & 168 & 7.77 & $\mathrm{x}$ & $\mathrm{x}$ & $\mathrm{x}$ & $\mathrm{x}$ & $\mathrm{x}$ & $\mathrm{x}$ & $\mathrm{x}$ \\
\hline ewis Creek South & 51.44 & 105.53 & $\mathrm{~N}$ & 1.9 & 1.36 & 21.1 & 8.74 & N.D. & 8.21 & $\mathrm{x}$ & $\mathrm{x}$ & $\mathrm{x}$ & $\mathrm{x}$ & $\mathrm{x}$ & $\mathrm{x}$ & $\mathrm{x}$ \\
\hline Lonetree & 49.08 & 108.26 & $\mathrm{~N}$ & 4.0 & 0.19 & 20.2 & 9.05 & 7.09 & 7.32 & $\mathrm{x}$ & $\mathrm{x}$ & $\mathrm{x}$ & $\mathrm{x}$ & $\mathrm{x}$ & $\mathrm{x}$ & $\mathrm{x}$ \\
\hline Macklin & 52.32 & 109.95 & $\mathrm{~N}$ & 2.8 & 0.8 & 20.2 & 8.38 & N.D. & 12.3 & $\mathrm{x}$ & $\mathrm{x}$ & $\mathrm{x}$ & $\mathrm{x}$ & $\mathrm{x}$ & $\mathrm{x}$ & $\mathrm{x}$ \\
\hline McDonald & 49.19 & 103.24 & $\mathrm{~N}$ & 14.5 & 0.25 & 20.0 & 8.48 & N.D. & 2.60 & $\mathrm{x}$ & $\mathrm{x}$ & $\mathrm{x}$ & $\mathrm{x}$ & $\mathrm{x}$ & $\mathrm{x}$ & $\mathrm{x}$ \\
\hline Newton & 49.32 & 107.83 & $\mathrm{~N}$ & 4.2 & 0.38 & 20.6 & 8.95 & 32.0 & 1.54 & $\mathrm{x}$ & $\mathrm{x}$ & $\mathrm{x}$ & $\mathrm{x}$ & $\mathrm{x}$ & $\mathrm{x}$ & $\mathrm{x}$ \\
\hline Nickle & 49.59 & 103.78 & $\mathrm{~N}$ & 5.7 & 0.25 & 19.2 & 8.17 & 37.6 & 2.27 & $\mathrm{x}$ & $\mathrm{x}$ & $\mathrm{x}$ & $\mathrm{x}$ & $\mathrm{x}$ & $\mathrm{x}$ & $\mathrm{x}$ \\
\hline Pasqua & 50.79 & 103.94 & $\mathrm{~T}$ & 12.5 & 0.77 & 21.2 & 8.78 & 23.7 & 5.59 & $\mathrm{x}$ & $\mathrm{x}$ & $\mathrm{x}$ & $\mathrm{x}$ & $\mathrm{x}$ & $\mathrm{x}$ & $\mathrm{x}$ \\
\hline Peter & 51.46 & 104.91 & $\mathrm{~N}$ & 0.5 & 2.78 & 22.4 & 9.49 & 165 & 12.6 & $\mathrm{x}$ & $\mathrm{x}$ & $\mathrm{x}$ & $\mathrm{x}$ & $\mathrm{x}$ & $\mathrm{x}$ & $\mathrm{x}$ \\
\hline
\end{tabular}




\section{ACCEPTED MANUSCRIPU}

$\begin{array}{cccccccccc}\text { Pike } & 51.90 & 106.82 & \mathrm{~N} & 2.5 & 0.26 & 19.6 & 8.66 & 2.47 & 12.8 \\ \text { Reflex } & 52.66 & 110.01 & \mathrm{~N} & 2.8 & 102 & 22.2 & 9.40 & 0.95 & 4.22 \\ \text { Round } & 50.54 & 102.37 & \mathrm{~N} & 10.4 & 0.83 & 21.4 & 8.82 & 26.6 & 4.31 \\ \text { Shrimp } & 51.59 & 108.45 & \mathrm{~N} & 3.0 & 0.41 & 22.6 & 9.05 & 23.9 & 11.8 \\ \text { Snipe } & 51.23 & 108.86 & \mathrm{~N} & 1.2 & 1.67 & 18.6 & 8.85 & 35.4 & 3.40 \\ \text { Stony Beach } & 50.50 & 105.19 & \mathrm{~S} & 2.7 & 0.35 & 22.1 & 9.53 & 1.08 & 6.00 \\ \text { Thackeray } & 52.54 & 108.69 & \mathrm{~N} & 1.6 & 1.17 & 19.6 & 9.42 & 24.7 & 8.17 \\ \text { Thomson } & 49.77 & 106.60 & \mathrm{~N} & 8.3 & 1.01 & 20.3 & 8.87 & 40.0 & \mathrm{~N} . \mathrm{D} . \\ \text { Unknown 3 } & 50.65 & 108.97 & \mathrm{~N} & 0.1 & 57.8 & 21.5 & 8.57 & \mathrm{~N} . \mathrm{D} . & 0.23 \\ \text { Vincent } & 50.22 & 108.94 & \mathrm{~N} & 0.1 & 49.9 & 22.0 & 9.42 & \mathrm{~N} . \mathrm{D} . & 2.61 \\ \text { WhiteBear } & 49.77 & 102.26 & \mathrm{~N} & 8.5 & 2.03 & 19.2 & 8.67 & 16.3 & 7.75 \\ \text { X3 } & 51.94 & 107.58 & \mathrm{~N} & 0.6 & 3.08 & 19.8 & 9.76 & 457 & 7.34 \\ \text { York } & 51.16 & 102.48 & \mathrm{~N} & 3.0 & 1.09 & 22.8 & 8.97 & 21.6 & 14.2\end{array}$

${ }^{\text {a }}$ Stratification: none $(\mathrm{N})$, stratified $(\mathrm{S})$, thermal $(\mathrm{T})$, meromictic $(\mathrm{M})$

${ }^{\mathrm{b}}$ SCR: Sulfate to Carbonate Ratio (Toney et al., 2010)

c $\% \mathrm{C}_{37: 4}=100 \times\left(\left[\mathrm{C}_{37: 4}\right] /\left[\mathrm{C}_{37} \mathrm{LCAs}\right]\right)$ (Rosell-Melé, 1998)

${ }^{\mathrm{d}} \mathrm{C}_{37} / \mathrm{C}_{38}=\left[\mathrm{C}_{37} \mathrm{LCAs}\right] /\left[\mathrm{C}_{38}\right.$ LCAs] (Volkman et al., 1995)

${ }^{\mathrm{e}} \mathrm{RIK}_{37}=\left[\mathrm{C}_{37: 3 \mathrm{a}}\right] /\left[\mathrm{C}_{37: 3 \mathrm{a}}+\mathrm{C}_{37: 3 \mathrm{~b}}\right]$ (Longo et al., 2016)

${ }^{\mathrm{f}} \mathrm{U}_{37}^{\mathrm{K}}=\left[\mathrm{C}_{37: 2}-\mathrm{C}_{37: 4}\right] /\left[\mathrm{C}_{37: 2}+\mathrm{C}_{37: 3}+\mathrm{C}_{37: 4}\right]$ (Brassell et al., 1986)

${ }^{\mathrm{g}} \mathrm{U}_{37}^{\mathrm{K}^{\prime}}=\left[\mathrm{C}_{37: 2}\right] /\left[\mathrm{C}_{37: 2}+\mathrm{C}_{37: 3}\right]$ (Brassell et al., 1986)

${ }^{\mathrm{h}} U_{37}^{\mathrm{K}^{\prime \prime}}=\left[\mathrm{C}_{37: 3}\right] /\left[\mathrm{C}_{37: 3}+\mathrm{C}_{37: 4}\right]$ (Zheng et al., 2016)

${ }^{\mathrm{i}} \mathrm{x}=$ not detected 


\section{Highlights}

- Alkenones (LCAs) were investigated in 106 lakes in the Canadian Prairies

- LCAs present in 55\% of surveyed lakes, with very high concentrations in $7 \%$ of lakes

- Salinity and stratification play key roles for LCA presence and abundance

- Improved seasonal sampling needed to better identify the timing of LCA production 